\title{
Molecular and Biochemical Effects of a Kola Nut Extract on Androgen Receptor-Mediated Pathways
}

\author{
Rajasree Solipuram, ${ }^{1}$ Sowmya Koppula, ${ }^{1}$ Angela Hurst, ${ }^{1,2}$ Kinesha Harris,,${ }^{1,2}$ \\ Srivatcha Naragoni, ${ }^{1}$ Krystal Fontenot, ${ }^{2}$ and Wesley Gray ${ }^{1,2}$ \\ ${ }^{1}$ Department of Environmental Toxicology, Southern University and A\&M College, P.O. Box 9264, \\ 108 Fisher Hall, Baton Rouge, LA 70813, USA \\ ${ }^{2}$ Department of Chemistry, Southern University and A\&M College, P.O. Box 9716, 116 Lee Hall, \\ Baton Rouge, LA 70813, USA \\ Correspondence should be addressed to Wesley Gray, dr1wggray@aol.com \\ Received 9 March 2008; Accepted 5 June 2008 \\ Recommended by Margaret James
}

\begin{abstract}
The low incidence of prostate cancer in Asians has been attributed to chemopreventative properties of certain chemicals found in their diet. This study characterized the androgenic and chemopreventative properties of the Jamaican bush tea "Bizzy," using androgen receptor positive and negative cell lines. Exposure of prostate cells to Biz-2 resulted in a growth inhibition $\left(\mathrm{GI}_{50}\right)$ of 15 ppm in LNCaP cells and 3.6 ppm in DU145 cells. Biz-2 elicited a 2-fold increase in the mRNA of the anti-apoptotic gene Bcl2, with a 10-fold increase in that of the proapoptotic gene Bax. We observed a 2.4- to 7.5-fold change in apoptotic cells in both cell lines. Biz-2 at 10 ppm elicited a time- and dose-dependent stimulation of both the protein and mRNA levels of several androgenregulated genes. Biz-2 caused a 36\% decrease in PSA secretion and a significant increase in PSA mRNA. The relative binding affinity $\left(\mathrm{IC}_{50}\right)$ of Biz-2 for AR was 2- to 5-fold lower than that of the synthetic androgen R1881. Biz-2 was found to be a specific ligand for the AR in that the natural ligand, DHT, and the anti-androgen, flutamide, displaced Biz-2 bound to AR and inhibited Biz-2-induced transcription and PSA secretion. This study provided evidence that Biz-2 extract possesses the ability to modulate prostate cancer cell biology in an AR-dependent manner.
\end{abstract}

Copyright ( 2009 Rajasree Solipuram et al. This is an open access article distributed under the Creative Commons Attribution License, which permits unrestricted use, distribution, and reproduction in any medium, provided the original work is properly cited.

\section{Introduction}

Nonsteroidal, plant-derived compounds that disrupt or mimic the normal action of estradiol are referred to as phytoestrogens. Those that disrupt or mimic the action of testosterone or dihydrotestosterone are referred to as phytoandrogens. These chemicals influence endocrine activity in animals and have been shown to play a role in the prevention of certain hormone-dependent cancers, such as breast and prostate cancers. The American Cancer Society estimated that 218,890 men in USA would be diagnosed with prostate cancer during 2007. Furthermore, they estimated that prostate cancer would kill 33,370 men in USA in 2007, making prostate cancer the fourth leading cause of cancer deaths in American men after lung cancer [1]. At the same time, African Americans have the highest incidence of prostate cancer and the highest mortality rate due to prostate cancer of any population studied. In Asian men from China, Japan, and Thailand, the incidence is much lower [2-4]. The low incidence of prostate disease in Eastern populations is attributed to dietary phytochemicals such as isoflavones, flavones, and lignans. Epidemiological studies suggest that the reduced risk of prostate disease in Asian populations is associated with consumption of foods rich in soy and vegetable products [5-7].

There is growing interest in using natural, dietary plant estrogens (phytoestrogens), particularly those found in soy products, as a potential chemopreventive regimen for prostate cancer. Several clinical trials and biochemical studies have been conducted to ascertain whether diets containing high levels of phytoestrogens may provide a chemopreventive benefit for prostate cancer patients $[3,8]$. Studies analyzing urinary excretion and prostatic fluid for the presence of phytoestrogens demonstrated that phytoestrogen 
values were higher in populations exhibiting a lower prostate cancer incidence $[9,10]$. A phytoestrogen-formulated diet reduces the number of spontaneous prostate-seminal vesicle tumors in rats predisposed to prostate tumors [11, 12]. In humans, prostate cancer patients who consumed high levels of phytoestrogens had lower levels of prostatespecific antigen, a common marker for prostate cancer $[6,13]$. In addition, organ culture studies showed that the phytoestrogen genistein decreased growth of prostate cancer tissue and benign prostatic hypertrophy [14-16]. Taken together, these studies suggest that some constituent of phytoestrogen-containing diets possesses antiandrogenic and antitumorogenic activities, which could provide some beneficial effects in prostate cancer patients [17].

Biologically active, nonsteroidal, androgenic, and estrogenic agents are found primarily in soy products, legumes, and whole grains. Other nontraditional sources include medicinal teas and roots. In some cultures, natural teas are consumed in large portions each day. Kola acuminate, also known as Obi or Bizzy nut to the Ettu people of Jamaica, is a "cure-all" herbal medicine. It reportedly affects many biological processes, many of which are directly, or indirectly, modulated by hormones. Available ethnobotanical information suggests that $K$. acuminate may contain bioactive chemicals that possess estrogenic and androgenic properties $[18,19]$. Anecdotal reports suggest that Bizzy nut may be useful for a number of medical purposes, such as removal of poisons from the body, birth control, control of diabetes, weight loss, and relief of menstrual cramps [20,21]. Given the hormonal dependency of some of these biological activities, it is possible that nonsteroidal androgen present in Bizzy nut extracts be responsible for the medicinal value attributed to it. Recently, we identified several hormonally active extracts of Bizzy nut that were capable of inhibiting the growth of different cancer cell lines [22].

In our laboratory, we are interested in natural products such as Bizzy nut, which contain phytoestrogens, phytoandrogens, or compounds that are antiandrogenic in nature. This article describes the putative androgenic effects of a Bizzy nut extract on pathways mediated by an androgen receptor (AR) in LNCaP cells. Herein, we describe the ability of a Bizzy nut extract to induce apoptosis in an AR-positive cell line and to modulate AR-dependent gene expression.

\section{Materials and Methods}

2.1. Cell Culture. LNCaP and DU145 cells were obtained from ATCC (Rockville, Md, USA). Cells were maintained in RPMI 1640 (LNCaP) or Kaighn's modification of Ham's F-12 (F12-K) medium supplemented with 10\% FBS, $0.2 \mathrm{mM}$ glutamine, $100 \mathrm{U} / \mathrm{mL}$ penicillin, and $100 \mathrm{mg} / \mathrm{mL}$ streptomycin. Cells were kept in $5 \% \mathrm{CO}_{2}$ in a water-jacketed incubator, and were passaged using a trypsin/EDTA solution (SigmaAldrich, Inc., St. Louis, Mo, USA) when they reached about 80-90\% confluency.

2.2. Pharmacological Treatments. LNCaP or DU145 cells $\left(1 \times 10^{5}\right)$ were grown in poly-d-lysine-coated, 6-well, or
$20 \mathrm{~cm}$ plates in Cellgro serum-free medium (Mediatech, Inc., Herndon, Va, USA) for 24 hours, then induced with varying amounts of Biz-2 (ether extract) or dihydrotestosterone (DHT). For time-course studies of induction, cells were induced for 6,12 , and 24 hours with the appropriate compound after which the medium was collected and concentrated using a CentriVap concentrator (Labconco, Kansas City, Mo, USA). The corresponding attached cells were extracted using RIPA buffer (Pierce Biotechnology, Rockford, Ill, USA), and stored at $-80^{\circ} \mathrm{C}$ until used. The ether extract of Bizzy nut (Biz-2) was prepared as previously described [22].

2.3. Cell Viability Analysis. For experiments involving cell growth and gene induction, LNCaP cells were grown for five days in RPMI 1640 medium containing 5\% FBS that was stripped three times with dextran-coated charcoal. Cells were then grown for 24 hours in Cellgro serum-free medium. Cells were plated in 96-well plates $\left(1 \times 10^{5}\right.$ cells/well) and allowed to attach overnight. The Biz-2 extract in $0.1 \%$ DMSO was added in a series of concentrations (0$1000 \mathrm{ppm})$ to a 96 -well plate. As a control and a reference, $10^{-7} \mathrm{M}$ genistein (GE) or $10^{-8} \mathrm{M}$ DHT was added to separate wells of each plate. Each treatment and time point had eight replicates. In each treatment, the final concentration of vehicle solvent did not exceed $0.01 \% \mathrm{v} / \mathrm{v}$ in the medium. After 24-hour exposure to the test compounds, the effect on cell viability and gene expression was determined. Cytotoxicity was determined by the CellTiter $96 \mathrm{AQ}_{\text {ueous }}$ One Solution cell proliferation assay (Promega Corporation, Madison, Wis, USA) according to the manufacturer's instructions. After incubation with 3-(4,5-dimethyl-2yl)-5-(3-carboxymethoxyphenyl)-2-(4-sulfophenyl)-2H-

tetrazolium, inner salt (MTS), absorbance at $490 \mathrm{~nm}$ was measured using an ELX800UV universal microplate reader (Bio-Tek, Inc., Winooski, Vt, USA). The cell viability was calculated as $\left[\left(\mathrm{A}_{490(\text { control })}-\mathrm{A}_{490 \text { (treatment) }}\right) / \mathrm{A}_{490 \text { (control) }}\right] \times 100$. For tryphan blue staining, cells were plated in 12-well plates (10000 cells/well) and induced with 100 ppm Biz-2 for 6, 12, or 18 hours. After induction, cells were harvested and stained with tryphan blue, and the number of cells was determined using a hemocytometer.

2.4. RNA Extraction and Real-Time RT-PCR Analysis. Total RNA was obtained from cells treated with 0-1000 ppm Biz2 extract, $10 \mathrm{nM} \mathrm{DHT}$, or $100 \mathrm{nM}$ GE in the presence or absence of 50-fold flutamide for 24 hours by lysing with $1 \mathrm{~mL}$ of TRI reagent (Invitrogen, Carlsbad, Calif., USA). The RNA pellet was resuspended in water, treated with RNasefree DNase I, reprecipitated, and quantified by reading the absorbance at 260 and $280 \mathrm{~nm}$ on an ND-1000 spectrophotometer (NanoDrop Tech., Wilmington, Del, USA).

For cDNA synthesis, 5 ug of DNase-I-treated total RNA were reverse-transcribed in a $100 \mathrm{uL}$ reaction mixture using the ABI High Capacity cDNA Archive Kit according to the manufacturer's instruction (Applied Biosystems, Foster City, Calif, USA). The reaction contained 1X RT buffer, $100 \mathrm{uM}$ of each deoxynucleoside triphosphate (dNTP), 1X 
TABLE 1: Regulation of androgen receptor target genes by Biz-2.

\begin{tabular}{|c|c|c|c|c|c|c|c|c|c|c|}
\hline \multirow{3}{*}{ Genes } & \multicolumn{9}{|c|}{ mRNA expression relative to control } & \multirow{3}{*}{ Gene description } \\
\hline & \multicolumn{3}{|c|}{$\begin{array}{c}\text { Biz-2 } \\
10 \mathrm{ppm}-24 \mathrm{~h}\end{array}$} & \multicolumn{3}{|c|}{$\begin{array}{c}\text { DHT } \\
10 \mathrm{nM}-24 \mathrm{~h}\end{array}$} & \multicolumn{3}{|c|}{$\begin{array}{c}\text { RES } \\
10 \mathrm{nM}-24 \mathrm{~h}\end{array}$} & \\
\hline & Fold & SEM & $N$ & Fold & SEM & $\mathrm{N}$ & Fold & SEM & $N$ & \\
\hline PSA & 10.55 & 2.26 & 3 & 8.09 & 0.91 & 3 & 3.66 & 0.18 & 3 & $\begin{array}{l}\text { Prostate-specific antigen: prostate tumor } \\
\text { marker }\end{array}$ \\
\hline NKX3-1 & 3.932 & 0.74 & 3 & 13.84 & 2.21 & 3 & 2.51 & 0.24 & 3 & $\begin{array}{l}\text { NK3 homeobox: a novel human } \\
\text { prostate-specific, androgen-regulated } \\
\text { homeobox gene associated with prostate } \\
\text { cancer progression }\end{array}$ \\
\hline TSC22 & 5.95 & 1.44 & 3 & 1.38 & 0.16 & 3 & 2.45 & 0.25 & 3 & $\begin{array}{l}\text { Tuberous sclerosis 22: a leucine zipper } \\
\text { transcription factor whose expression is } \\
\text { induced by TGF-b }\end{array}$ \\
\hline PART-1 & 1 & 0.3 & & 0.35 & 0.02 & & - & - & - & $\begin{array}{l}\text { Prostate androgen-regulated transcript } 1: \\
\text { androgen-inducible gene that is regulated } \\
\text { by androgens and phytoestrogen }\end{array}$ \\
\hline $\mathrm{ER} \beta$ & 1.17 & 0.4 & 3 & 1.08 & 0.32 & 3 & 1.27 & 0.21 & 3 & $\begin{array}{l}\text { Estrogen receptor } \beta \text { : nuclear transcription } \\
\text { factor that mediates transcription of } \\
\text { nonsteroidal and steroidal ligands }\end{array}$ \\
\hline $\mathrm{ER} \alpha$ & 1.36 & 0.281 & 3 & 1.36 & 0.281 & 3 & 1.48 & 0.35 & 3 & $\begin{array}{l}\text { Estrogen receptor } \alpha \text { : ligand-inducible } \\
\text { nuclear transcription factor that mediates } \\
\text { estrogen-dependent gene expression in } \\
\text { females }\end{array}$ \\
\hline AR & 2.84 & 0.20 & 3 & 1.271 & 0.11 & 3 & 0.44 & 0.01 & 3 & $\begin{array}{l}\text { Androgen receptor: transcription factor } \\
\text { that mediates transcription of genes } \\
\text { required for development of male } \\
\text { reproductive tissues }\end{array}$ \\
\hline Bcl2 & 2.68 & 2.68 & 3 & 0.85 & 0.07 & 3 & 1.14 & 0.12 & 3 & $\begin{array}{l}\text { B cell leukemia/lymphoma-2: an } \\
\text { antiapoptotic protein known to regulate } \\
\text { apoptotic pathway and protect against } \\
\text { cell death }\end{array}$ \\
\hline Bax & 9.97 & 2.13 & 3 & 7.64 & 0.09 & 3 & 3.45 & 0.17 & 3 & $\begin{array}{l}\text { Bcl2-associated X-protein: a proapoptoti } \\
\text { protein that regulates apoptotic pathway } \\
\text { and promotes cell death }\end{array}$ \\
\hline
\end{tabular}

random primer, $5 \mathrm{U}$ of RNase inhibitor, and $250 \mathrm{U}$ of reverse transcriptase II. The reaction was carried out at $25^{\circ} \mathrm{C}$ for 10 minutes then at $37^{\circ} \mathrm{C}$ for 2 hours. Control reactions were those in which the RT enzyme or the target RNA was omitted from the reaction.

Taqman PCR was performed on the cDNA samples using an ABI PRISM 7500 Sequence Detection System (Applied Biosystems). For each gene tested (see Table 1), the PCR was carried out in a multiplex mode with every $25 \mathrm{uL}$ reaction containing $2 \mathrm{uL}$ of cDNA reaction, $1 \mathrm{X}$ Taqman universal PCR master mix, $250 \mathrm{nM}$ of a gene-specific primer, $250 \mathrm{nM}$ of an endogenous control primer, $250 \mathrm{nM}$ of FAMlabeled fluorogenic Taqman probe, a VIC-labeled 18S rRNA fluorogenic control Taqman probe, and $2.5 \mathrm{U}$ of TaqMan enzyme. The PCR amplification was conducted using a Taqman Universal PCR Master Mix (Applied Biosystems) at universal thermal cycling conditions: $50^{\circ} \mathrm{C}$ for 2 minutes, $95^{\circ} \mathrm{C}$ for 10 minutes, 40 cycles at $-95^{\circ} \mathrm{C}$ for 15 seconds, and $60^{\circ} \mathrm{C}$ for 1 minute. An increase in fluorescence was obtained at the annealing and extension step at $60^{\circ} \mathrm{C}$.

The relative level of expression of each gene in the samples was determined using the relative $2^{\Delta \Delta C_{t}}$ expression method as described in detail in the ABI PRISM Sequence Detection System User Bulletin 2 [23]. After the linear range of amplification (threshold cycle, $C_{t}$ ) was determined for the genes of interest, it was normalized against an endogenous $18 \mathrm{~S}$ rRNA control and then against the untreated control sample, which served as the calibrator. The value of the relative level of expression for the gene of interest represents two independent inductions performed in triplicate.

2.5. Ligand Binding Analysis. The binding affinity of Biz-2 to the Androgen receptor was evaluated on whole-cell, LNCaP extract or on $10 \mathrm{nM}$ of the baculovirus-expressed ligand binding domain of the AR (PanVara, Madison, Wis, USA) 
[24, 25]. Samples (100 uL) containing $250 \mathrm{ug}$ of total protein in $1 \mathrm{X}$ binding buffer (10 mM HEPES, pH 7.9, 10\% glycerol, 0.02\% Ficoll 400, $100 \mathrm{mM} \mathrm{NaCl,} \mathrm{0.1} \mathrm{mM} \mathrm{EDTA,} 2.5 \mathrm{mM}$ for each of $\mathrm{MgCl}_{2}, \mathrm{CaCl}_{2}$, and DTT, and $1 \mathrm{~g} / \mathrm{mL}$ for each of leupeptin, pepstatin, antipain, aprotinin, soybean trypsin inhibitor, and chymostatin) were incubated with $2 \mathrm{nM}\left[{ }^{3} \mathrm{H}\right]-$ R1881 in the presence or absence of a 10 -fold serial dilution

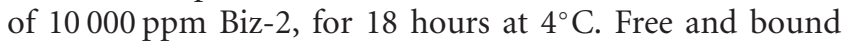
radioligands were separated using the hydroxyapatite assay. Bound radioligand was measured by scintillation counting as previously described [26]. Specific binding was determined by subtraction of nonspecific binding from total binding. The $\mathrm{IC}_{50}$ (the concentration of competitor that results in $50 \%$ of maximal binding) and $K_{i}$ (the competitor binding constant assuming $1 \mathrm{nM} K_{d}$ for radiolabeled ligand) were determined by fitting the data to the Cheng-Prusoff equation [27] using the Prism III software program (GraphPad, San Diego, Calif, USA).

2.6. Fluorescence Microscopy. For microscopy, $5 \times 10^{5}$ cells (LNCaP or DU145) were grown on microscope slides and induced with 0,100 , and 500 ppm of Biz-2 for 24 hours. On each slide, cells were stained for 5 minutes with $5 \mu \mathrm{L}$ of a $0.1 \mathrm{ug} / \mathrm{uL}$ solution of acridine orange and ethidium bromide. Two fluorescence parameters, green emission from acridine orange $(525 \mathrm{~nm})$ and red emission from ethidium bromide $(620 \mathrm{~nm})$, were examined under a fluorescence light microscope (Nikon Optiphot, Melville, NY, USA) for the nuclear changes that are typically associated with apoptosis. An index of apoptosis was calculated as the ratio of the number of cells per microscopic field with early and late apoptosis characteristics in treated samples relative to the total number of cells per microscopic field.

2.7. Analysis of Caspase 3/7 Activation. Caspase 3/7 activity was determined using an Apo-One Homogeneous Caspase3/7 Assay kit (Promega Corporation) according to the manufacturer's instructions. Briefly, cells were grown in test medium to a density of $1 \times 10^{6}$ cells $/ \mathrm{mL}$. The cells were then treated with Biz-2, antigen, or a combination of the two, as indicated, for 12 or 24 hours. Following induction, cells were harvested by incubation in $5 \mathrm{~mL}$ of harvesting solution at $37^{\circ} \mathrm{C}$ for $5-10$ minutes. The cells were collected by centrifugation. The pellets were resuspended in $100 \mathrm{uL}$ of hypotonic cell lysis buffer (25 mM HEPES, pH 7.5, $5 \mathrm{mM} \mathrm{MgCl}_{2}, 5 \mathrm{mM}$ EDTA, $5 \mathrm{mM}$ DTT, and $2 \mathrm{mM}$ PMSF). The samples were subjected to two rounds of freezing and thawing in liquid $\mathrm{N}_{2}$, then centrifuged at $14000 \times g$ for 15 minutes. Caspase 3/7like activity was determined based on proteolytic cleavage of rhodamine 110, bis-(N-CBZ-L-aspartyl-L-glutamyl-L-valylL-aspartic acid amide, Z-DEVD-R110). The free rhodamine 110 was quantified on a SpectraMax Gemini Fluorescence Spectrophotometer with excitation at $499 \mathrm{~nm}$ and emission at $521 \mathrm{~nm}$ using the SoftMax Pro program in static mode. The Caspase 3/7-like activity in each sample was determined from the maximum fluorescence after 3 hours. Recombinant Caspase 3 served as a positive control for the assay.

2.8. Western Blot Analysis. Immunoblot of the LNCaP protein fraction was performed as previously described $[28,29]$.
Briefly, LNCaP cells grown under the indicated condition were lysed at $4^{\circ} \mathrm{C}$ in RIPA buffer supplemented with $1 \mathrm{X}$ sigma protease inhibitor cocktail (Sigma-Aldrich, Inc.). A BCA protein assay kit (Pierce Biotechnology) was used to determine protein concentration. An aliquot of the total protein sample (30 ug) was size-fractionated using a 10\% or a $4-20 \%$ precast (SDS-PAGE) gel (Pierce Biotechnology), then the fractionated proteins were transferred to a polyvinylidene difluoride (PVDF) membrane (Immobilien, Millipore, Bedford, Mass, USA). The membrane was blocked with 5\% nonfat dry milk in TBST buffer $(10 \mathrm{mM}$ Tris$\mathrm{HCl}, \mathrm{pH} 8,150 \mathrm{mM} \mathrm{NaCl}$, and $0.1 \%$ Tween-20) for 1 hour at room temperature, and immunostained with the following antibodies: $0.5 \mathrm{ug} / \mathrm{mL}$ anti-Bcl2 and $0.5 \mathrm{ug} / \mathrm{mL}$ anti-Bax (Santa Cruz Biotechnology Inc., Santa Cruz, Calif, USA), $1.5 \mathrm{ug} / \mathrm{mL}$ anti-AR and $0.5 \mathrm{ug} / \mathrm{mL}$ anti-GDPH (Cell Signaling, Danvers, Mass, USA). The blots were washed three times with TBST buffer, and immunoreactive proteins were detected using a 1 : 20,000 dilution of antirabbit IgG horseradish peroxidase (Amersham, Arlington Heights, Ill, USA) at room temperature for 1 hour. The bands were visualized using an enhanced chemiluminescence detection system (Pierce Biotechnology) according to the instructions of the manufacturer. The immunoblot signal was captured using an AlphaInnotech Fluorochem HD 9900 (AlphaInnotech, San Leandro, Calif, USA) equipped with a CDD camera. The images were analyzed with the AlphaEaseFC software (AlphaInnotech), and curves and graphs were fitted with GraphPad Prism 3.0 software (GraphPad) [30].

2.9. Analysis of PSA Secretion by Immunoassay. The total amount of prostate-specific antigen (PSA) secreted by LNCaP cells was quantified under different experimental conditions using a two-site sandwich, colorimetric base ELISA kit according to the manufacturer's instructions (CBI PSA ELISA kit, Calbiotech, Inc., Spring Valley, CA, USA). Briefly, $1 \times 10^{7}$ cells were treated with Biz-2, phytoestrogen, or DHT as indicated. The conditioned medium was removed and centrifuged at $12000 \mathrm{rpm}$ for 5 minutes to remove any detached cells. An aliquot of the medium (1 or $10 \mathrm{uL}$ ) was added to each well of a 96-well plate, precoated with antiPSA antibody. The unbound PSA in the sample was allowed to bind. The unbound PSA was then removed by washing. The horseradish peroxidase-labeled PSA enzyme conjugate was added for 30 minutes followed by the addition of the colorimetric terminating message buffer substrate, and the color change was read at an absorbance of $570 \mathrm{~nm}$ using an $\mathrm{EL}_{X} 800 \mathrm{UV}$ universal microplate reader (Bio-Tek, Inc.). To quantify the relationship between absorbance and the concentration of PSA, a standard curve $(0-50 \mathrm{ng} / \mathrm{mL})$ was prepared from PSA solutions of known concentration. The results were expressed as nanograms of PSA per $\mathrm{mL}$ of conditioned medium, and were adjusted to nanograms per mg of secreted protein.

2.10. Determination of Cell Proliferation Using Thymidine Incorporation. Thymidine incorporation was measured as previously described [28]. Briefly, cells were plated at a density of $1 \times 10^{4}$ cells/well in 96-well plates, and incubated 
overnight. Biz-2 in $0.1 \%$ dimethyl sulfoxide was added at a series of concentrations $(0-1000 \mathrm{ppm})$ to eight wells each of a 96-well plate, and incubated for 24 hours. After adding $0.5 \mathrm{uCi} /$ well of [methyl ${ }^{3} \mathrm{H}$ ] Thymidine, plates were incubated for 6 hours. The medium was removed and cells were harvested onto a Whatman 934-AH glass microfiber filter (Fisher Scientific, Pittsburgh, Pa, USA) using a 96-well filtration manifold. To lyse the cells, filters were washed with $0.2 \mathrm{mM} \mathrm{NaOH}$. Filters were then washed with $70 \%$ ethanol and dried with 95\% ethanol. The filter paper was cut into 96 distinct pieces, placed in scintillation vials containing $3 \mathrm{~mL}$ of liquid scintillation fluid (MP Biomedicals, Solon, Ohio, USA), and counted in a TriCarb 2200CA scintillation counter (Packard, Medien, Conn, USA).

2.11. Solid-Liquid Extraction and TLC Analysis. A $10 \mathrm{~g}$ sample of finely ground Bizzy root was sequentially extracted in a Soxhlet apparatus using $500 \mathrm{~mL}$ of $100 \%$ hexane, ether, acetone, methane, or water, solvents with increasing polarity. The extraction mixture was allowed to reflux for 24 hours at temperatures corresponding to the boiling point of the respective solvent and the extraction monitored by TLC chromatography. Following extraction, particulate matter was removed by filtering the samples through a $0.45 \mu \mathrm{m}$ glass-fritted filter, and the extract was evaporated to dryness using a combination of simple distillation and rotary evaporation. The residue of each extract was resuspended in DMSO to a concentration of $10000 \mathrm{ppm}$. Aliquots (100 ppm) of each extract were run on thin-layer chromatography plates (Silica Gel Hl, Analtech, Newark, DE, USA; ca. $10 \mathrm{~cm}$ wide $\times 20 \mathrm{~cm}$ high) using a solvent of $40 \% \mathrm{v} / \mathrm{v}$ Ether- $60 \% \mathrm{v} / \mathrm{v}$ Hexane. The analytes were visualized under ultraviolet light, and the image was captured digitally using a FluorChem HD Alpha Innotech System.

2.12. Statistical Analysis. All numerical data were expressed as mean \pm SEM. In each assay, three or four measurements were made. Means for the treatment groups were compared using analysis of variance and Duncan's multiple range test $(P<.05)$. To analyze the absorbance density from western blot data, a two-tailed $t$-test $(P<.05)$ was used to compare the mean $(n=3)$ for each treatment group with the mean for the untreated control group. The GraphPad Prism 3.0 software program (GraphPad) was used for the statistical analyses [30].

\section{Results}

3.1. Activation of an Androgen-Dependent Pathway by Biz2. The androgenic potential of natural compounds is manifested in a variety of biological responses including induction of cell growth, secretion of cellular protein, and receptordependent gene expression. Secretion of PSA by the prostate is a hallmark of prostatic function. Furthermore, modulation of PSA level is used as a biomarker in assessing prostate development and function. As an initial step in identifying and characterizing medicinally relevant, putative, selective androgen receptor modulators (SARMs) present in Bizzy

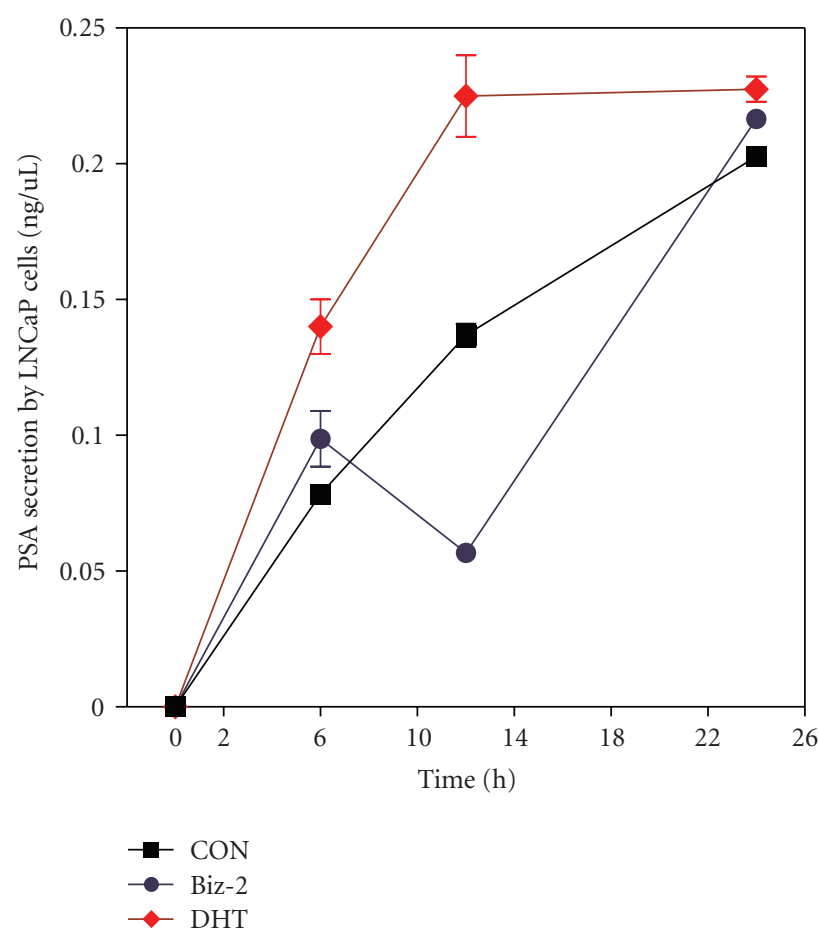

(a)

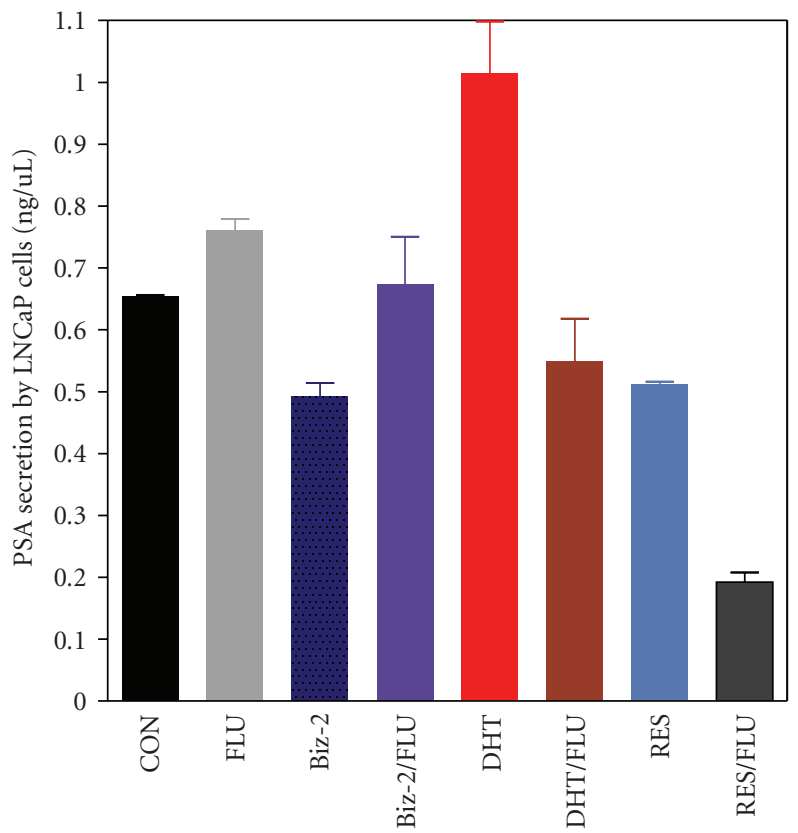

(b)

Figure 1: Biz-2 modulates PSA secretion by LNCaP cells. LNCaP cells $\left(1 \mathrm{E}^{7}\right)$ were grown in serum-free medium for 24 hours, then induced with $100 \mathrm{ppm}$ of Biz-2 for $0,6,12$, and 24 hours. Equal aliquots $(10 \mathrm{uL})$ of the condition medium were removed and analyzed by PSA ELISA (see Section 2). (a) Time-dependent secretion of PSA. (b) PSA secretion induced with $10 \mathrm{ppm} \mathrm{Biz-}$ 2 for 24 hours in the presence and absence of $10 \mathrm{nM}$ flutamide. The values are the mean \pm SEM of three separate experiments performed in triplicate. CON: control; DHT: dihydrotestosterone; Biz-2: ether extract of Bizzy nut; RES: resveratrol. 


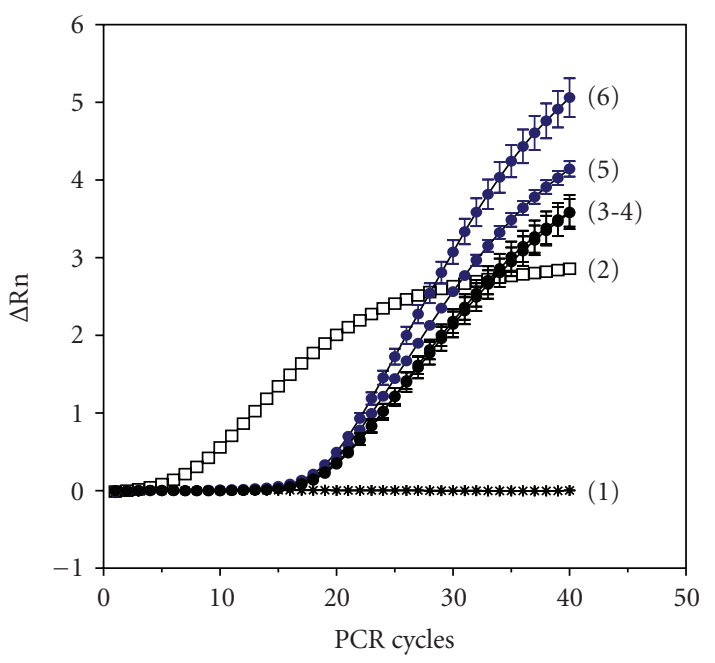

(a)

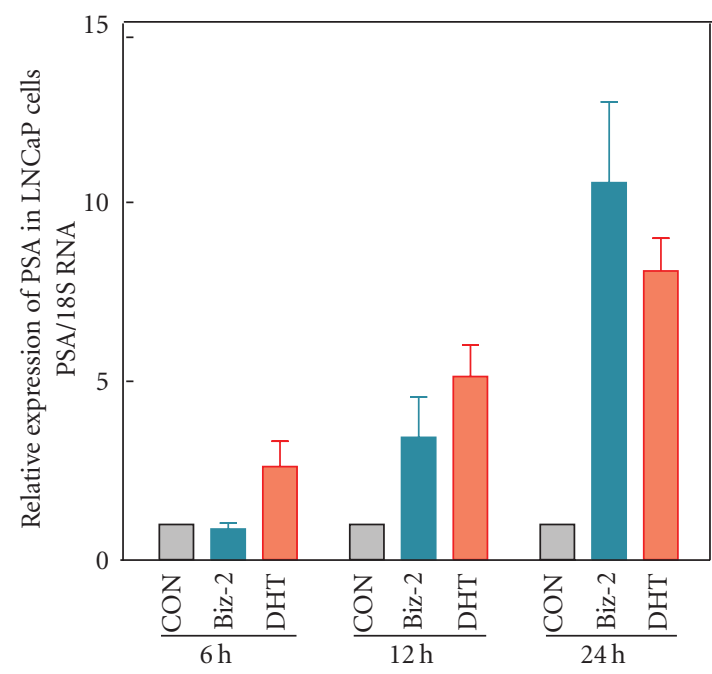

(b)

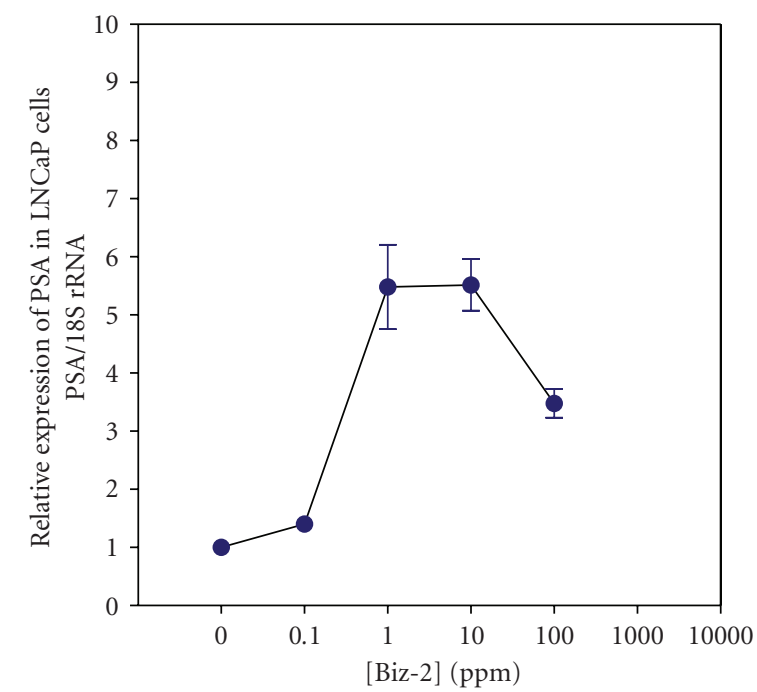

(c)

FIGURE 2: Stimulation of PSA mRNA expression by Biz-2. LNCaP cells were induced with Biz-2 or DHT, and $5 \mu$ g of DNase-I-treated RNA isolated from induced or uninduced cells were subjected to two-step Taqman real-time RT-PCR (see Section 2). The relative expression of PSA mRNA expression was calculated by the $2^{\Delta \Delta C_{t}}$ method. First, relative quantitation of PSA mRNA expression was performed by first normalizing the $C_{t}$ values of PSA amplification against the $C_{t}$ values of endogenous $18 \mathrm{~S}$ rRNA, then the resulting $C_{t}$ values were normalized using the $C_{t}$ value of the vehicle control sample. (a) Relative amplification plot of mRNA expression (1-NTC. 2-18S rRNA at 24 hours, 3 and $4-\mathrm{CON}$ at 6 and 24 hours, 5 and 6- Biz-2 at 6 and 24 hours). (b) PSA mRNA expression relative to time. (c) Dose-dependent response of PSA to Biz-2. The values are mean \pm SEM of induction samples analyzed in triplicate.

nut, we performed solid-liquid extraction using solvents of increasing polarity. We screened each extract for bioactivity using several in vitro assays that were designed to reveal if any of the extracts contained androgenic or estrogenic activity [22]. We determined whether an ether extract of Bizzy nut (Biz-2) was capable of modulating prostate function by exerting its effect on PSA secretion by LNCaP cells. LNCaP cells were grown in a serum-free medium for 24 hours, and then induced with $100 \mathrm{ppm}$ of Biz-2 for 6,12 , or 24 hours. A PSA ELISA was then used to determine the concentration of PSA in the medium. PSA secretion by LNCaP cells in the presence of Biz-2 displayed a biphasic response (Figure 1(a)). Relative to control, Biz-2 induced an initial $26.59 \pm 13.3 \%$ increase in PSA after the first 6 hours of exposure. The level of PSA decreased by $32.6 \pm 1.3 \%$ during the second sixhour period, and increased by $25.93 \pm 3.3 \% 12$ hours later (Figure 1(a)). In contrast, DHT produced a time-dependent increase $(9.6 \pm 6.7 \%$ and $130 \pm 6 \%$ after 12 and 24 hours, resp.) in PSA production under the same experimental conditions (Figure 1(a); data not shown).

To understand the relationship between Biz-2 modulation of PSA secretion and the androgen-dependent pathway, 
we determined whether the PSA secretion was mediated by a Biz-2/androgen receptor interaction. To answer this question, PSA secretion was measured in the presence of the antiandrogen flutamide (FLU) (Figure 1(b)). As a positive control, we measured PSA secretion in the presence of flutamide with or without the natural androgen, DHT. Consistent with previous studies [31, 32], flutamide blocked the AR-dependent stimulation of PSA $(1.014 \pm 0.08 \mathrm{ng} / \mathrm{uL}$ for DHT versus $0.549 \pm 0.07 \mathrm{ng} / \mathrm{uL}$ for DHT/FLU) by LNCaP cells. Treatment of LNCaP cells with 10 ppm Biz-2 plus $1 \mathrm{nM}$ of flutamide prevented the Biz-2 inhibition of PSA secretion (Figure 1(b)). At $10 \mathrm{ppm}$ Biz-2, PSA levels decreased by $24.80 \pm 3.4 \%$ of control, that is, from $0.654 \pm 0.01 \mathrm{ng} / \mathrm{uL}$ to $0.492 \pm 0.022 \mathrm{ng} / \mathrm{uL}$. Addition of flutamide at $1 \mathrm{nM}$ restored the PSA level to that of control $(0.673 \pm 0.077 \mathrm{ng} / \mathrm{uL} \mathrm{Biz-}$ $2 / F L U$ versus $0.654 \pm 0.03 \mathrm{ng} / \mathrm{uL}$ control). In our system, there was a significant increase $(16 \pm 2.8 \%, n=8, P<.01)$ in PSA secretion in the presence of FLU, suggesting that there may have been residual androgen present in the medium. Alternatively, flutamide may have induced an androgenic effect on PSA under serum-free conditions (Figure 1(b)). Nevertheless, FLU was able to prevent the Biz-2-induced decrease in PSA secretion, which was an observation that was complimentary to what we observed with DHT/FLU treatment. These results strongly suggested that the Biz2 inhibition of PSA secretion was dependent on the AR pathway.

\subsection{Transcriptional Inhibition of an Endogenous Androgen-} Regulated Gene by Biz-2. Modulation of PSA secretion in the presence of Biz-2 may have resulted from changes in PSA mRNA production, and could have been independent of the secretion processes that were present in LNCaP cells. To test this hypothesis, we measured PSA mRNA levels in cells exposed to Biz-2 using Taqman real-time RT-PCR. Multiplex real-time PCR was performed using a primer/probe set specific for PSA and 18S rRNA (PE Applied Biosystems, Foster City, Calif, USA). The expression levels of PSA were obtained from DNase-I-treated total RNA, and were normalized to those of the $18 \mathrm{~S}$ rRNA gene, which served as the calibrator for our experiments. The logarithm of the fluorescence intensity of each probe versus the number of cycles and the level of expression of mRNA of PSA in LNCaP cells was evaluated (Figure 2). In the present study, the mRNA expression of PSA was determined using the $2^{\Delta \Delta_{t}}$ method, and is expressed relative to the control sample which is set to 1 . We observed a time-dependent increase in levels of PSA mRNA between 6 and 24 hours of exposure in the presence of $10 \mathrm{ppm} \mathrm{Biz-2} \mathrm{(Figure} \mathrm{2(b)).}$ Analysis of the data in Figure 2(b) also indicated that, after treatment with Biz-2 or the positive control (DHT), levels of PSA mRNA expression showed a statistically significant increase. Exposure of LNCaP cells to $10 \mathrm{ppm}$ Biz-2 resulted in a $0.87 \pm 0.17$-fold increase in PSA mRNA, which was increased by 12 -fold $(0.87 \pm 0.17$ to $10.56 \pm 2.25)$ in the second 12-hour period. We determined the potency of Biz2 in stimulating PSA mRNA by exposing LNCaP cells to different amounts of Biz-2 for 24 hours. The response of

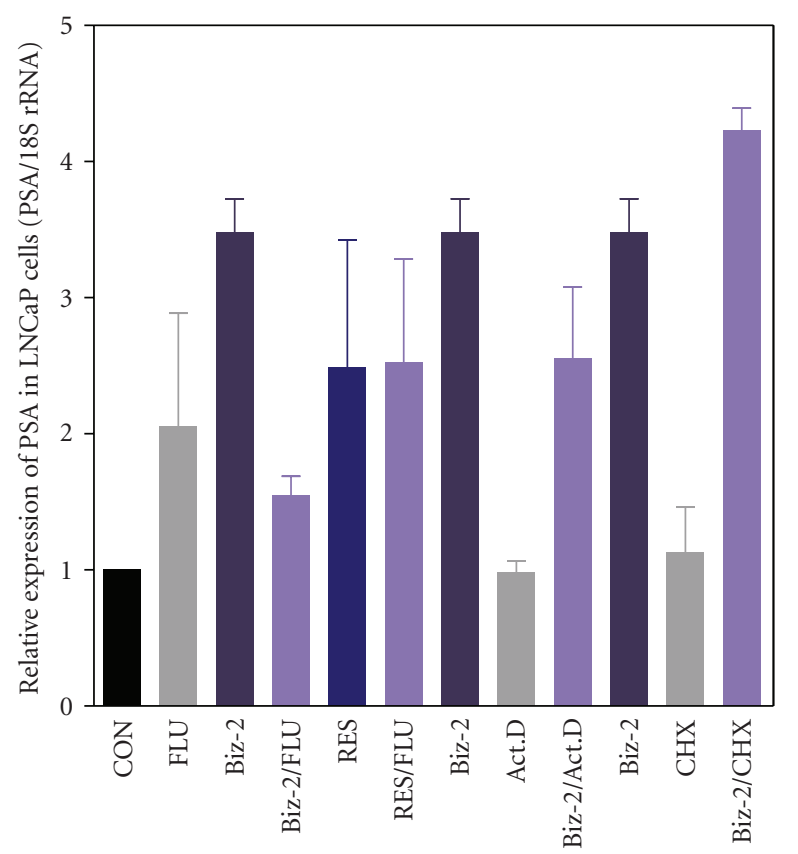

Figure 3: Flutamide inhibition of Biz-2 stimulation of PSA mRNA expression. LNCaP cells were induced with Biz-2 in the presence or absence of flutamide, and RNA from induced or uninduced cells was subjected to two-step Taqman real-time RT-PCR. Relative quantitation of PSA mRNA expression was preformed as described in Figure 2. CON: vehicle control; FLU: flutamide; Biz-2: Bizzy nut extract-2; RES: resveratrol; Act.D: actinomycin-D; CHX: cycloheximide. The values are the mean \pm SEM of three separate experiments performed in triplicate.

PSA mRNA production to Biz-2 concentration was bellshaped (Figure 2(c)). At concentrations below 10 ppm, Biz-2 elicited a dose-dependent increase in PSA mRNA expression, whereas at high concentrations (100 ppm and greater) expression of PSA was inhibited. Biz-2 at low concentrations produced a similar increase in PSA mRNA at 12 and 24 hours as the endogenous androgen DHT (Figure 2(b); data not shown).

To substantiate the observation that Biz-2 modulated PSA activity in an AR-dependent manner, we measured Biz2 -induced PSA mRNA in the presence of the AR antagonist flutamide. The Biz-2-induced expression of PSA mRNA was inhibited by $55 \%(3.46 \pm 0.25$-fold Biz- 2 to $1.55 \pm 0.14$ fold Biz-2/Flu) in the presence of $1 \mathrm{nM}$ flutamide (Figure 3) suggesting that Biz-2 mediated an increase in PSA mRNA level through an interaction with the AR present in $\mathrm{LNCaP}$ cells. On the other hand, resveratrol, a phytoestrogen with bioactivity in LNCaP cells, induced a 1.5-fold increase in PSA mRNA levels, which was independent of the AR (Figure 3). Next we ascertained whether the stimulatory effects of Biz2 on PSA expression were a result of RNA stability by measuring the mRNA levels of PSA in the presence and absence of actinomycin-D, a known transcription inhibitor. Pretreatment of LNCaP cells with $5 \mathrm{ug} / \mathrm{uL}$ of actinomycin-D for 4 hours resulted in a 26\% inhibition of PSA expression relative to Biz-2. At the same time, blocking of protein 
synthesis using cycloheximide resulted in an increase in the Biz-2-induced expression of PSA (Figure 3). Because actinomycin-D alone could not have induced PSA mRNA synthesis, our data suggested that Biz-2 regulated PSA expression directly at the level of transcription.

3.3. Modulation of AR-Dependent Gene Expression by Biz2. To further characterize the effects of Biz-2 on the ARdependent pathway, we examined the androgenic effects of Biz-2 on the transcription activity of three androgenregulated genes (PSA, PART-1, and NKX3-1) [33-35] and three steroid receptor genes (ER- $\beta, \operatorname{ER} \alpha$, and $\operatorname{AR})[36,37]$ using real-time, quantitative, two-step RT-PCR (Table 1). Biz-2 produced a robust induction in the three androgenregulated genes tested (Table 1 ). We ascertained the specificity and the strength of induction of androgen-specific genes by Biz-2 by determining the relative gene expression at $10 \mathrm{ppm} \mathrm{Biz-2}$ or $10 \mathrm{nM}$ DHT. We observed that Biz-2 was as effective as DHT in inducing the expression of the well-known prostate-specific gene (PSA). Biz-2 at $10 \mathrm{ppm}$ produced $10.55 \pm 2.2-, 3.9 \pm 0.74-$, and $5.95 \pm 1.4$-fold inductions of PSA, NKX3-1, and TSC22 mRNA levels, respectively. Relative to $\mathrm{DHT}, \mathrm{Biz}-2$ was six times more effective in stimulating TSC22 expression (Table 1). Biz-2 showed a marginal increase in expression levels of steroid receptor genes $(\mathrm{ER} \alpha: 1.4 \pm 0.3$; $\mathrm{ER} \beta: 1.2 \pm 0.4$; $\mathrm{AR}: 2.8 \pm$ 0.2 ) suggesting differential regulation of androgen-regulated genes by Biz-2 in LNCaP cells (Table 1). Biz-2 was able to stimulate each prostate-specific, AR-dependent gene 2-fold to 8 -fold relative to control. Taken together, we surmised that Biz-2 had a major influence on AR-dependent gene activation in LNCaP cells.

3.4. Components of Bizzy Nut Extract that Bind to the AR with High Affinity. To corroborate our gene expression data and to provide further evidence that the effects of Biz-2 are AR-mediated, we measured the ability of Biz-2 to bind to the AR. We examined the ability of Biz-2 to compete with ${ }^{3}$ [H]R1881 for binding to AR using purified, recombinantexpressed AR, LNCaP cells, which contained high levels of the mutated form of AR [38], or cells transfected with the wild-type pCMV-AR expression plasmid. A pCMV-AR expression plasmid was transfected into either LNCaP or DU145 cells, and the ability of the transfected cells to bind to Biz-2 specifically was measured using a competition receptor binding assay $[28,39]$. LNCaP cells were chosen because they are AR-positive. The DU145 cells were chosen as a null environment because they are AR-negative. The concentration of Biz-2 that reduced the specific binding of ${ }^{3}[\mathrm{H}] \mathrm{R} 1881$ by $50 \%$ $\left(\mathrm{IC}_{50}\right)$ was determined by incubating protein obtained from transfected and nontransfected cells with $2 \mathrm{nM}^{3}[\mathrm{H}] \mathrm{R} 1881$ in the absence and presence of increasing concentration of Biz2. Biz-2 was able to displace ${ }^{3}[\mathrm{H}] \mathrm{R} 1881$ bound to the mutant androgen receptor in $\mathrm{LNCaP}$ cells, purified recombinant receptor, or the wild-type receptor protein (Figure 4(a)). Biz2 displayed high-affinity binding to both the mutant and the wild-type AR, suggesting that the T877A mutation of the LNCaP AR was not responsible for the Biz-2/AR biology. The

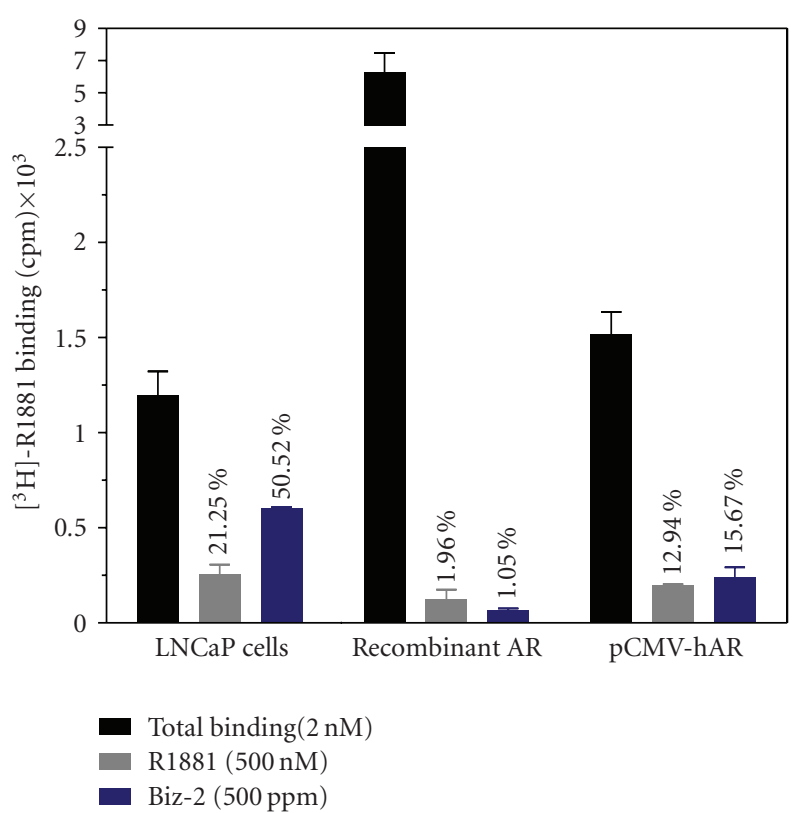

(a)

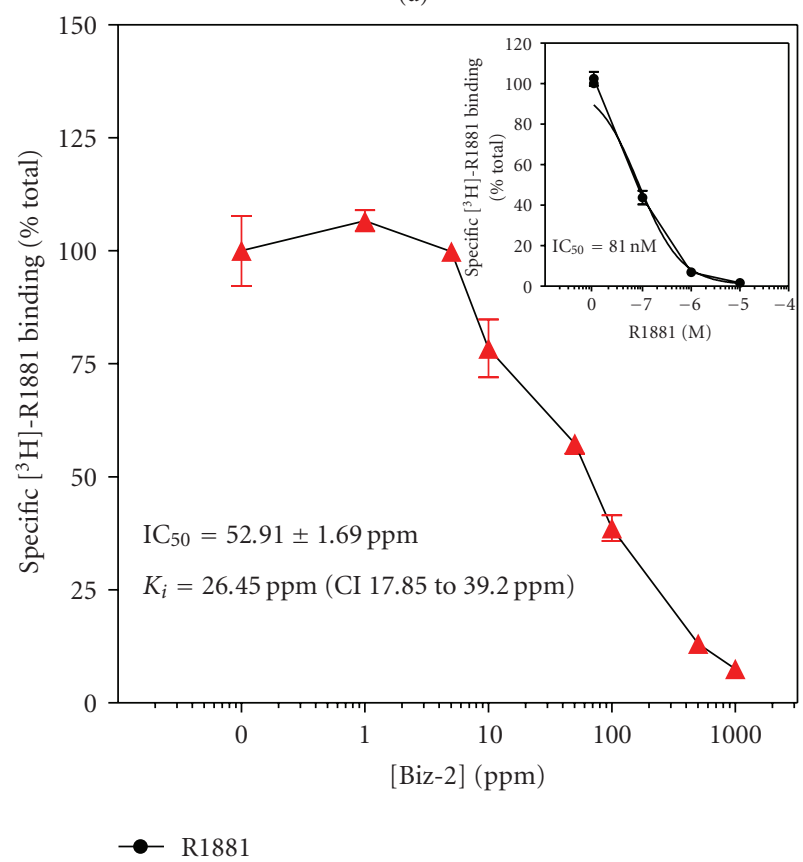

(b)

FIGURE 4: Biz-2 competes for AR binding in LNCaP cells. AR protein from LNCaP cells, cells transfected with pCMV-AR, or purified recombinant AR protein was incubated with $2 \mathrm{nM}\left[{ }^{3} \mathrm{H}\right]$ R1881 with or without increasing concentration of Biz-2 for 18 hours at $4^{\circ} \mathrm{C}$. Bound and free $\left[{ }^{3} \mathrm{H}\right] \mathrm{R} 1881$ were separated using the HAP assay (see Section 2). Each data point represents the mean \pm SEM of a representative experiment performed in triplicate. The $\mathrm{IC}_{50}$ was calculated from the competition curve using a one-site competition model. $K_{i}$ was calculated by $K_{i}=\mathrm{IC}_{50} /\left(1+[\right.$ ligand $\left.] / K_{d}\right)$ in which $K_{d}$ and ligand concentration [ligand] were set to 1 and $2 \mathrm{nM}$, respectively. (a) Single-point assay in the presence of 500X excess R1881 (number above the bar is \% of total binding). (b) Displacement curve of $\left[{ }^{3} \mathrm{H}\right] \mathrm{R} 1881$ by Biz-2 (insert is displacement curve of $\left[{ }^{3} \mathrm{H}\right] \mathrm{R} 1881$ by inert R1881). $N=2$ separate experiments performed in triplicate. 
AR binding affinity $\left(\mathrm{IC}_{50}\right.$ and $\left.K_{i}\right)$ of Biz-2 was determined from the competition assay, because the assay was performed under conditions where the ${ }^{3}[\mathrm{H}] \mathrm{R} 1881$ and the competing Biz-2 were not depleted. The $\mathrm{IC}_{50}$ and apparent $K_{i}$ for Biz2 binding to $\mathrm{AR}$ were obtained by fitting the radioligand competitive data to the Cheng-Prusoff equation [27]. The $\mathrm{IC}_{50}$ was determined from nonlinear regression of the data fitted to a one-site competition binding, where the $K_{d}$ for ${ }^{3}[\mathrm{H}] \mathrm{R} 1881$ binding to $\mathrm{AR}$ was assumed to be $1 \mathrm{nM}$ (Figure 4(b)). The calculated $K_{i}$ and $\mathrm{IC}_{50}$ for Biz-2 binding to the wild-type or LNCaP AR were 26.45 (CI 17.85 to 39.20) and $52.91 \pm 1.69 \mathrm{ppm}(P<.05)$, respectively. Comparison of the $K_{i}$ of Biz-2 to that of R1881 binding to the AR suggested that Biz-2 was only $13 \mathrm{X}$ less potent in binding to the AR.

\subsection{Components of Biz-2 Extract are Inhibitory to Proliferation} of LNCaP Cells. Biz-2 at high concentrations reduced PSA secretion by LNCaP cells, but increased PSA mRNA levels. At these high concentrations, components of Biz-2 may have induced necrotic or apoptotic events in LNCaP cells. To test this hypothesis, we determined whether Biz-2 exerted any cytotoxic effects using MTT viability and a ${ }^{3}[\mathrm{H}]$-thymidine proliferation assay. The cytotoxicity of Biz- 2 was determined in both the AR-positive LNCaP and AR-negative DU145 cells. Biz-2 at less than $20 \mathrm{ppm}$ was capable of inducing cell death (proliferation inhibition) in more than 50\% of LNCaP cells (Figure 5). In addition, Biz-2 was more effective in inducing death in DU145 cells at the concentrations tested (Figure 5(a)). Next we determined the potency of Biz-2 in inhibiting survival of LNCaP and DU-145 cells. The $\mathrm{GI}_{50}$ of Biz-2 was determined by plotting the thymidine data as a dose-response curve with a variable slope. Maximal inhibition of LNCaP cell growth by Biz-2 was achieved at $50 \mathrm{ppm}$ with a $\mathrm{GI}_{50}$ of $14.69 \pm 1.16 \mathrm{ppm}$ (Figure 5(a)). Biz2 was five times more potent in the androgen-independent cell line, DU145, than in the LNCaP cells. Both MTT and tryphan blue staining demonstrated a significant decrease in cell viability after 6 hours at $100 \mathrm{ppm}$ Biz-2 (Figure 5(b)). Biz-2 induced $31.44 \%$ and $35.63 \%$ decreases in LNCaP cell viability and cell number, respectively (Figure 5(b)). To corroborate the ${ }^{3}[\mathrm{H}]$-thymidine incorporation assay, we evaluated the effect of Biz-2 on LNCaP cell proliferation using MTT exclusion as an index of cell cytotoxicity. Within 24 hours of exposure to Biz-2, cell viability decreased with dose (Figure 5(c)). This decrease was similar to that observed with the thymidine incorporation assay (Figure 5(a)). The lethal dose concentration $\left(\mathrm{LD}_{50}\right)$ and the growth inhibitory concentration $\left(\mathrm{GI}_{50}\right)$ of Biz-2 on LNCaP cells were $14.69 \pm$ $1.16 \mathrm{ppm}$ and $15.24 \pm 0.24 \mathrm{ppm}$ in the MTT and $\left[{ }^{3} \mathrm{H}\right]$ thymidine incorporation assays, respectively. Taken together, these results suggested that in LNCaP cells, high concentration of Biz-2 elicits a cytotoxic effect that is time-dependent and may reduce cell proliferation and increase the frequency of cell death.

3.6. Biz-2-Induced Apoptosis and Cell Cycle Arrest in LNCaP Cells. Our current data suggest that in AR-positive LNCaP cells, Biz-2 is cytotoxic, which presumably leads to inhibition of cell proliferation. Therefore, we examined the mechanism of Biz-2 cytotoxicity. We investigated whether the observed cytotoxicity was a result of a chemically induced cellular cytotoxicity or cell-induced apoptosis. We hypothesized that Biz2 could be cytotoxic because it ruptures plasma membranes. That is, we hypothesized that a necrotic reaction, but not programmed cell death, was responsible for the cytotoxity of Biz-2. Therefore, we examined whether the initial cellular cytotoxicity of Biz-2 was related to the extent of apoptosis. LNCaP cells $\left(5 \times 10^{5}\right)$ were grown, induced with increasing concentration (0.1-100 ppm) of Biz-2, and prepared for microscopic examination as described in Section 2. Slides were examined under a fluorescent light microscope for the nuclear changes that are typical of apoptosis. Microscopic examination of apoptotic cells revealed that there was a dosedependent increase in apoptosis of both LNCaP and DU145 cells following 24-hour exposure to Biz-2. Examination of cells treated with Biz- 2 by phase-contrast microscopy showed a dramatic decrease in cell number and cellular shrinkage (Figures 6(a) and 6(b)). Fluorescence staining with acrydine orange and ethidium bromide revealed signs of nuclear condensation, nuclei fragmentation, and membrane budding, which are all hallmark features of apoptosis (Figures 6(a) and 6(b), bottom panels). Light microscope analysis of cells

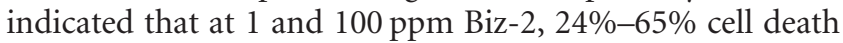
occurred in LNCaP cells, whereas, only $5 \%-15 \%$ cell death was observed in DU145 cells after a 24-hour exposure. The apoptotic index was determined for both LNCaP and DU145 by quantifying the relationship between dose of Biz-2 and apoptosis (Figure 6(c)). We calculate the apoptotic index by averaging the number of apoptotic cells per field (70-60 cells) then dividing by the total number of cells per field (120-140 cells). In the case of LNCaP cells, apoptosis was strongly related to cytotoxicity (Figures 5 and 6(c)). We observed a greater degree of apoptosis in the AR-positive LNCaP cells as compared to the AR-negative cell, DU145. A concentration of Biz-2 of $10 \mathrm{ppm}$ induce $20-25 \pm 3 \%$ apoptosis in LNCaP as compared to $10-12 \pm 4 \%$ in DU145 cells. As the concentration of Biz- 2 was increased to 10 and $100 \mathrm{ppm}$, the frequency of apoptotic cells increased in both cell lines (Figure 6(c)).

3.7. Bizzy Nut Extract Induces Activation of Early Apoptosis Gene. To gain an understanding of the relationship between Biz-2-induced cytotoxicity and apoptosis, we examined the expression of several key apoptosis genes. The temporal dynamics of Bcl2 and Bax during Biz-2-induced cytotoxicity in LNCaP cells was assessed using western blot analysis and QRT-PCR. Bcl2 protein was detectable in LNCaP cells grown in serum-free medium for 48 hours. Induction with $0.1 \mathrm{ppm}$ of Biz-2 resulted in a 4 -fold increase in Bcl2 protein and mRNA (Figure 7(a) and Table 1). Following the initial stimulation by Biz-2, the decrease in $\mathrm{Bc} 12$ protein expression was dose-dependent. The decrease in Bcl2 levels with the increase in Biz-2 probably was not due to metabolism of this compound, because there was a time-dependent increase in Bcl2 at 10 ppm Biz-2 (data not shown). Similarly, when we analyzed the dose-dependent expression of the 


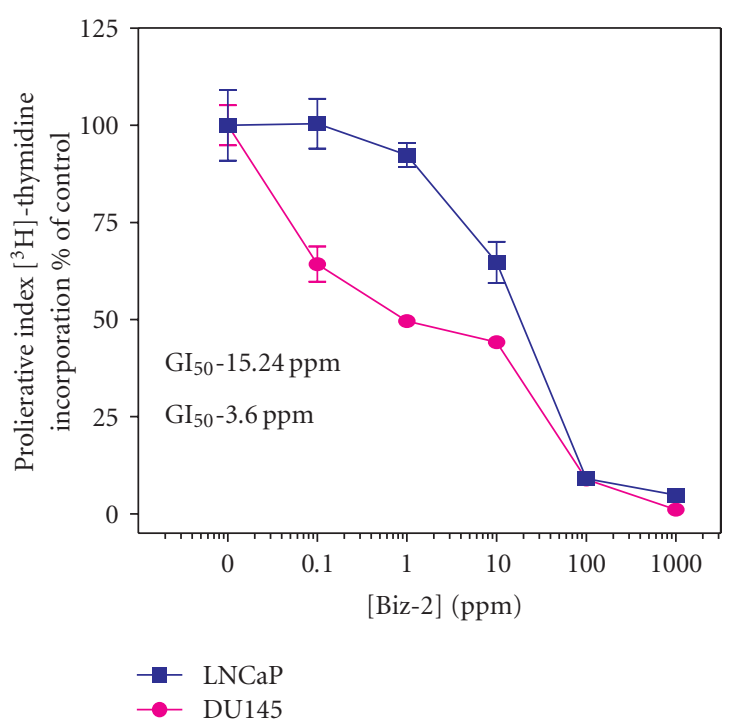

(a)

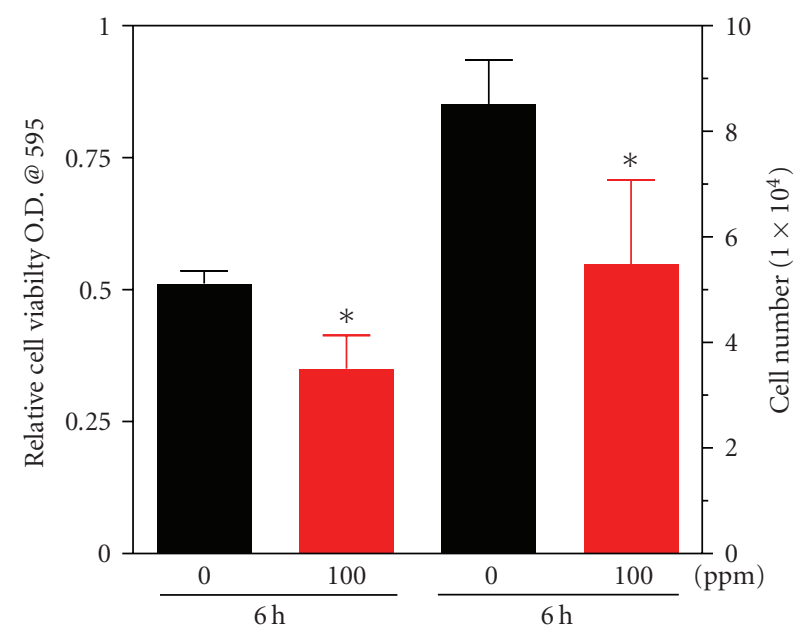

(b)

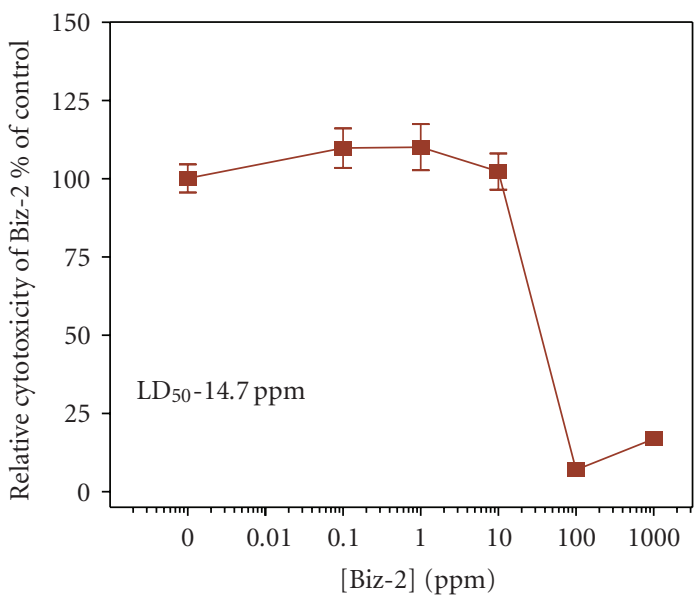

MTT assay

(c)

FIGURE 5: Modulation of prostate cell proliferation by Bizzy nut extracts. LNCaP or DU145 cells were grown in the presence of 0-1000 ppm Biz-2 for 24 hours, and cell growth was determined using $(\mathrm{a})^{3}[\mathrm{H}]$ thymidine incorporation, (b) MTT cell viability assay and tryphan blue dye staining, and (c) cytotoxicity of Biz-2 in LNCaP cells that was performed as described in Section 2. Growth inhibitory activity of the extracts was determined as $\left[\left(\mathrm{A}_{490(\text { control })}-\mathrm{A}_{490(\text { extract })}\right) / \mathrm{A}_{490 \text { (control) }}\right] \times 100$. Each value represents mean \pm SEM for three experiments performed in eight wells of a 96 -well plate. Values followed by $* P<.05$ differed significantly from the controls.

proapoptotic protein Bax in the presence of Biz-2, there was a slight increase (0.5-1.3-fold) in Bax protein and a dramatic increase (9.97-fold as compared to control) in its mRNA expression within the first 12-24 hours of exposure (Figure 7(a) and Table 1). The decrease in both Bax and Bcl2 proteins after 24-hour exposure to $100 \mathrm{ppm}$ Biz-2 appeared to be related to the time-dependent decrease in both proteins (Figure 7(a); data not shown). Because the Bax and Bcl2 protein levels were important in the release of a key factor early in the apoptotic cascade, we determined the $\mathrm{Bax} / \mathrm{Bcl} 2$ ratio in the presence of $\mathrm{Biz}-2$. Bax/Bcl2 levels decreased with increasing concentration of Biz-2. At a high concentration, the LNCaP appeared to recover from the initial apoptotic event induced by Biz- 2 .

We validated the morphological analysis and protein assessment of Biz-2-induced apoptosis by ascertaining if the protein activity of the downstream apoptotic protein Caspase 3/7 had been modulated in the presence of Biz-2. The level of active Caspase- 3 was measured by proteolytic cleavage of rhodamine 110, from the bis-(N-CBZ-L-aspartylL-glutamyl-L-valyl-L-aspartic acid amide) (Z-DEVD-R110) substrate. There was a dose-dependent increase in Biz2-induced cytotoxicity in LNCaP cells $(0.1-10 \mathrm{ppm})$ as evidenced by the 2.5-fold increase in Caspase $3 / 7$ activity 

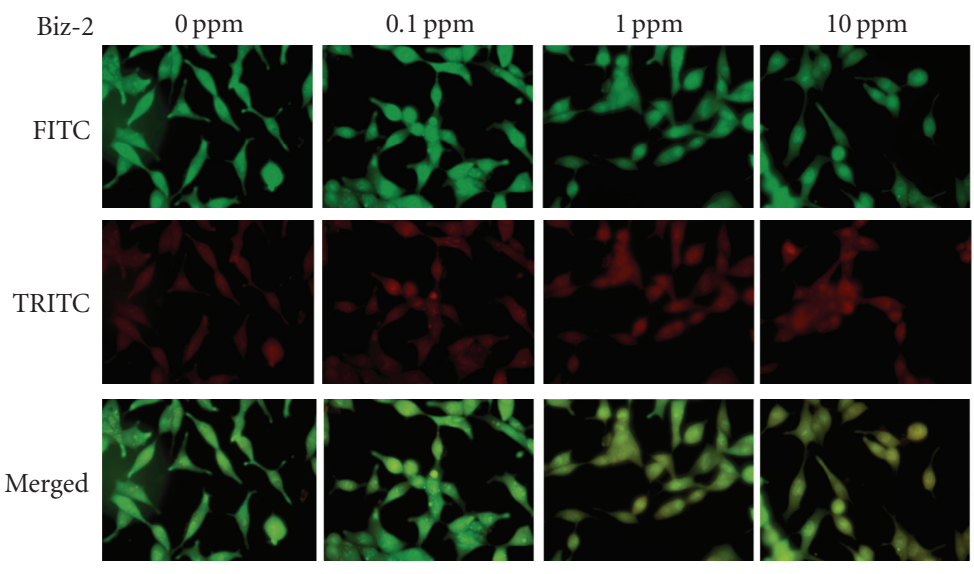

$100 \mathrm{ppm}$
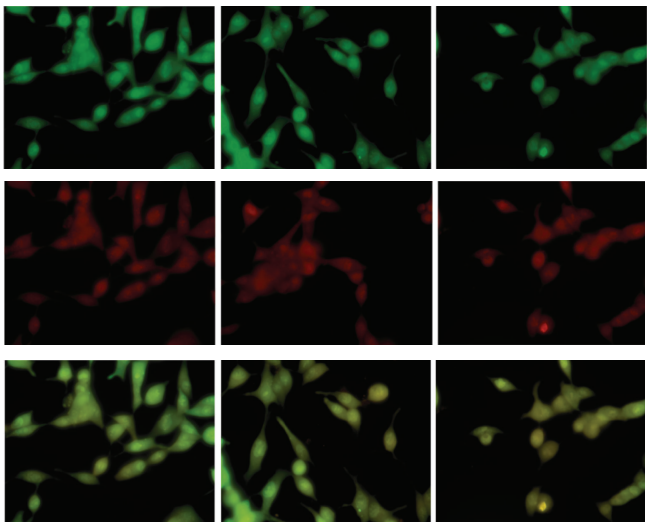

(a)

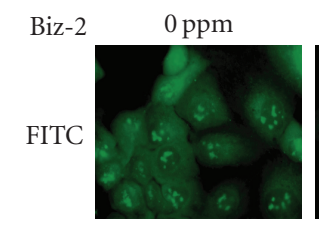

$0.1 \mathrm{ppm}$

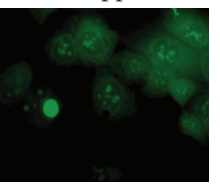

$1 \mathrm{ppm}$

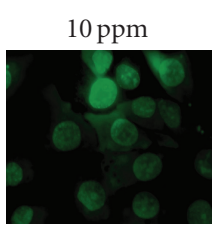

$100 \mathrm{ppm}$
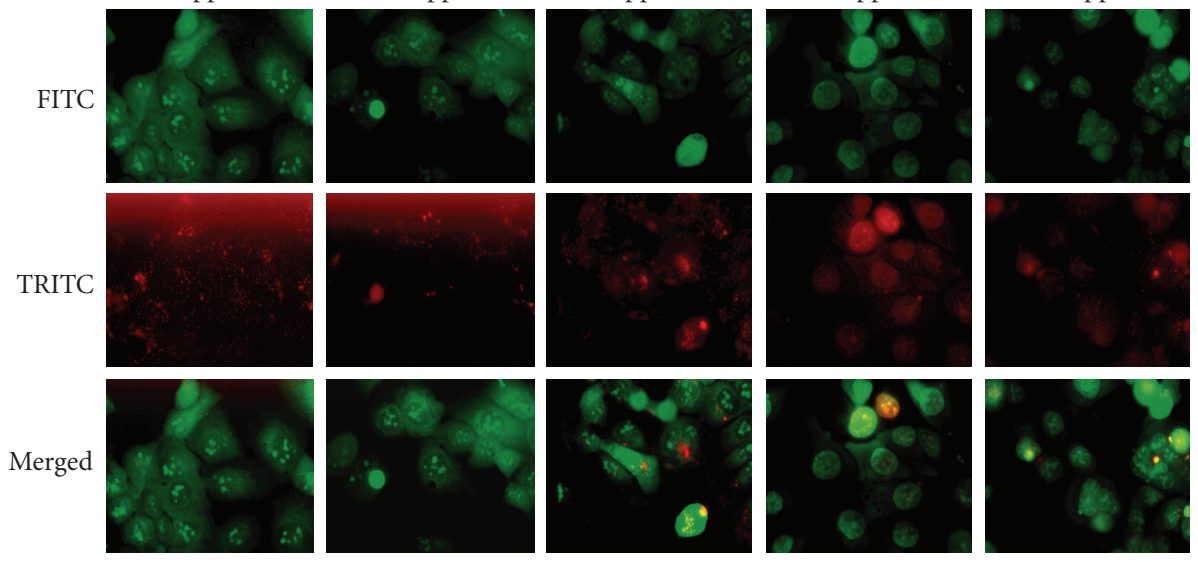

(b)

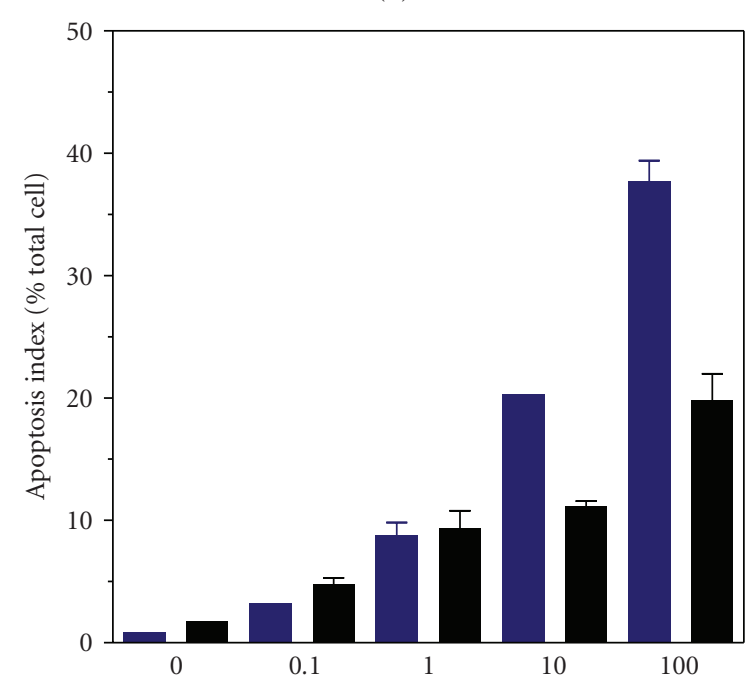

[Biz-2] (ppm)

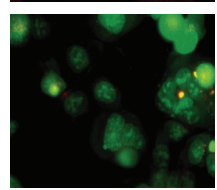

DU-145 cells

LNCaP cells

(c)

Figure 6: Cellular and nuclear morphology indicative of apoptosis induced by Biz-2. LNCaP cells were grown on a microscope slide, then induced with 1 or $100 \mathrm{ppm}$ of Biz-2 for 24 hours. Cells were stained with a solution of acridine orange and ethidium bromide for 5 minutes, then examined by light microscopy. (a) Confocal laser fluorescent microscope images taken with a $550 \mathrm{~nm}$ filter (Top panel: acridine orange, middle panel: ethidium bromide, bottom panel: both). (b) Apoptotic index was determined. We calculate the apoptotic index by averaging the number of apoptotic cells per field (70-60 cells), then dividing by the total number of cells perfield (120-140 cells) (total number of cells - total number of apoptotic cells)/(total number of cells). 


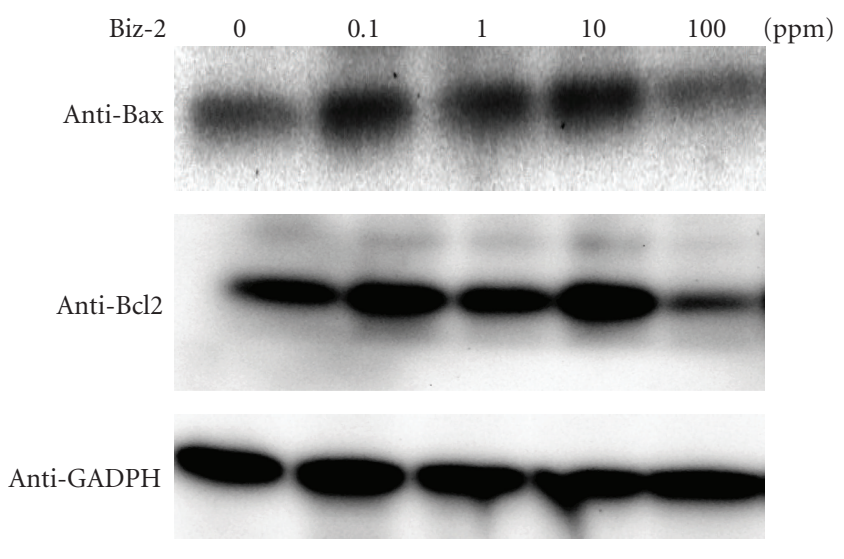

(a)

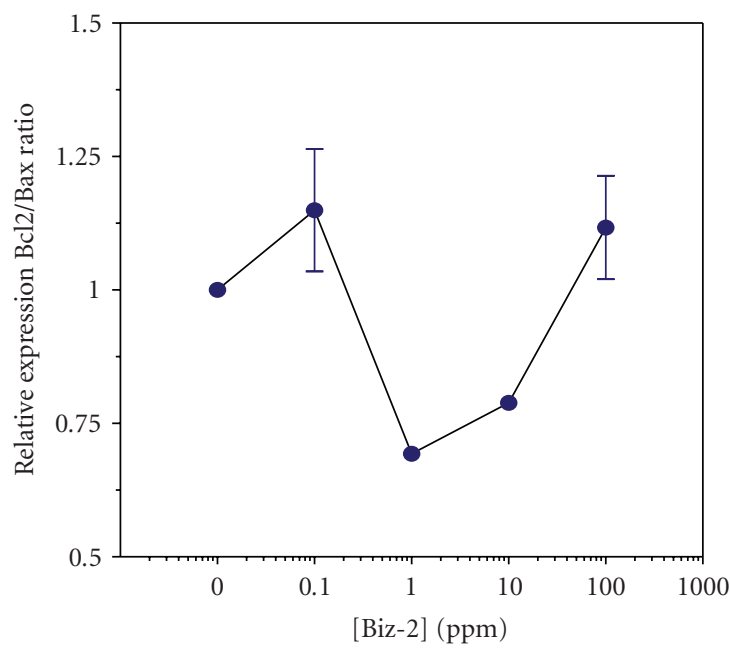

$\mathrm{Bcl} 2 / \mathrm{Bax}$

(b)

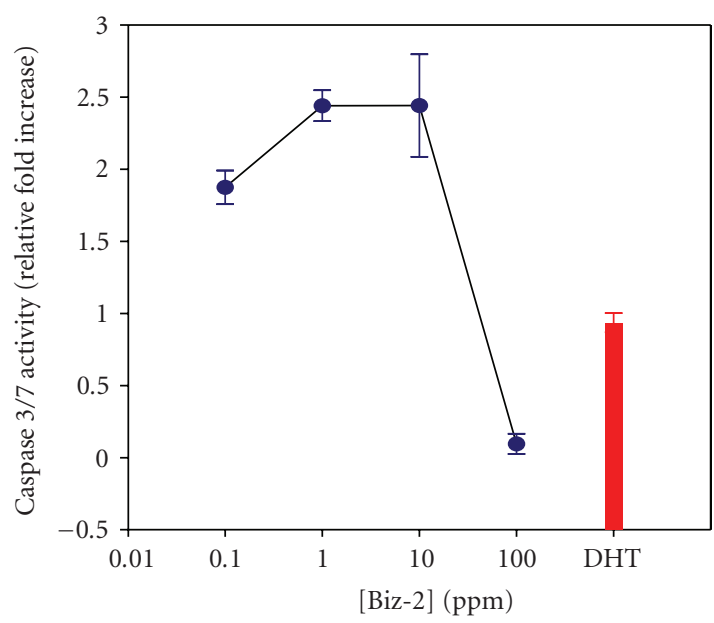

(c)

Figure 7: Modulation of apoptotic protein levels in the presence of Biz-2. LNCaP cells were grown in a serum-free medium in the presence of increasing concentrations of Biz-2 for 24 hours. Whole-cell extracts were isolated with RIPA buffer, and $30 \mu \mathrm{g}$ of protein extract were analyzed by immunoblotting for Bcl-2, Bax, AR, and GDPH expression. (a) Immunoblot of Biz-2-induced proteins. (b) Ratio of Bcl2/Bax expression. (c) Biz-2 induces increase in Caspase $3 / 7$ activity.

relative to the untreated control (Figure $7(\mathrm{c})$ ). In the analysis of time-dependent Caspase 3/7 activity in the presence of 100 ppm Biz-2, Caspase 3/7 activity decreased significantly relative to the untreated control within the first 6 hours of induction, which suggested that a high concentration of Biz2 inhibited apoptosis in LNCaP cells (Figure 7(c); data not shown).

3.8. Biz-2 Modulation of Apoptotic Pathway in LNCaP Cells is Mediated through an AR Pathway without New Protein Synthesis. We used the protein synthesis inhibitor cycloheximide (CHX) and the AR antagonist flutamide (FLU) to investigate (a) whether Biz-2-induced apoptosis required protein synthesis and (b) if Biz-2-induced apoptotic processes use an
AR signaling pathway (Figure 8). Treatment of $\mathrm{LNCaP}$ with $1 \mathrm{ug} / \mathrm{mL}$ of CHX for 12 hours after induction with $100 \mathrm{ppm}$ Biz-2 resulted in an inhibition of Biz-2-induced Caspase 3/7 activity and $\mathrm{Bax}$, and $\mathrm{Bcl} 2$ protein expression (Figure $8(\mathrm{~b})$; data not shown). At low concentration, Biz-2 stimulated Caspase 3/7 activity 1-2-fold. CHX completely abolished the Biz-2-stimulated Caspase levels, which suggested that the effect of Biz-2 on Caspase required protein synthesis. The analysis of Caspase 3/7 activity and Bax expression in the presence and absence of actinomycin-D implied that Biz-2 did not elicit a direct transcription effect on Bax or Caspase levels because pretreatment with actinomycin-D had no effect on their expression (Figure 8(b); data not shown).

To corroborate the CHX data and to generate further evidence that Biz-2-modulated apoptosis in LNCaP cells 


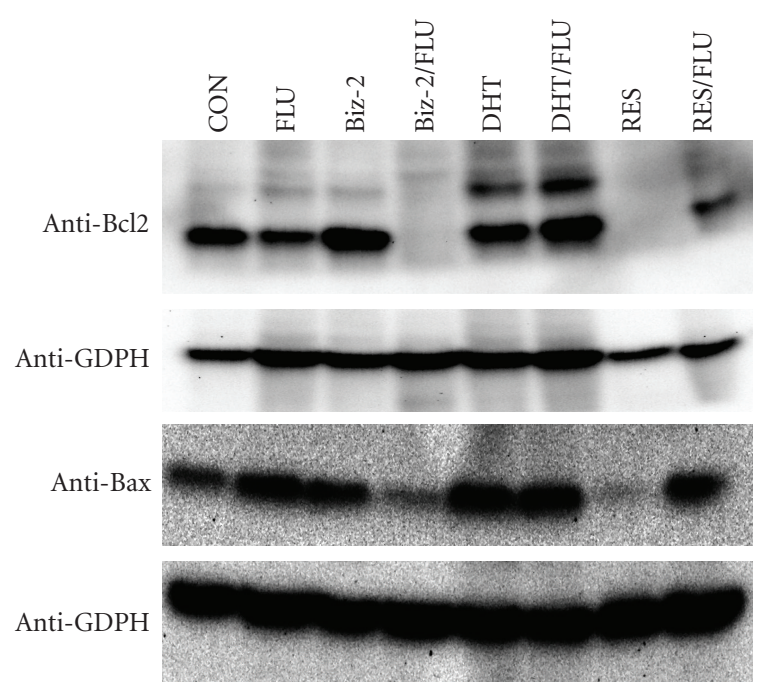

(a)

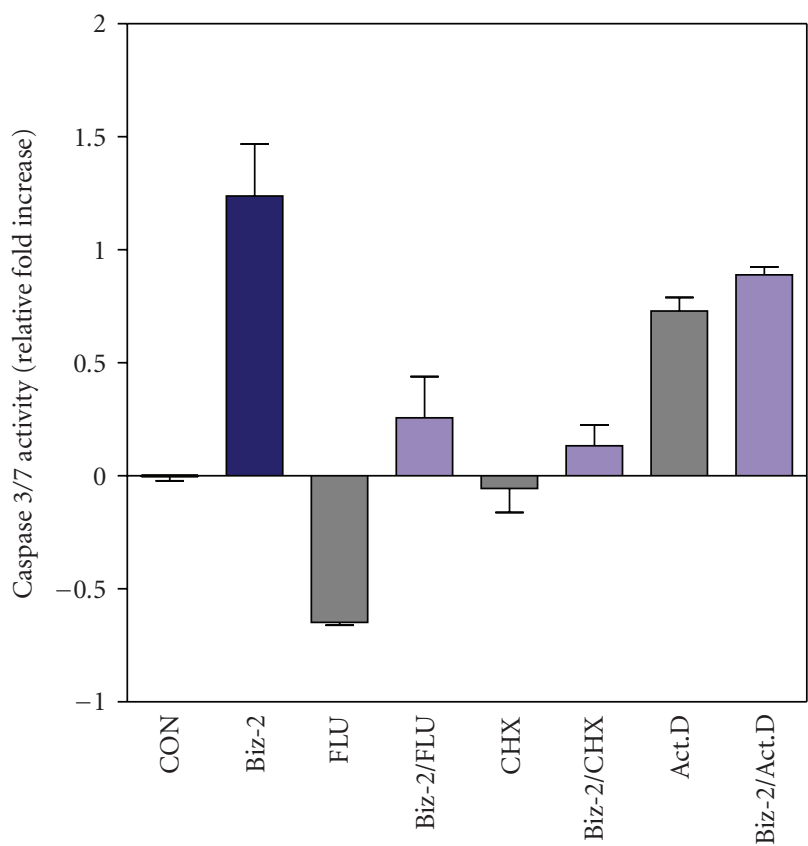

(b)

Figure 8: Biz-2 increases Caspase 3/7 levels in LNCaP cells. LNCaP cells $\left(1 \times 10^{6}\right)$ were grown in test medium and induced with 100 ppm Biz-2 for 24 hours, and the resulting Caspase 3/7 activity was determined using the Apo-One Homogeneous Caspase-3/7 assay as described in Section 2. (a) Western blot of Bcl2 and Bax proteins following induction of LNCaP with Biz-2 in the absence and presence of flutamide. (b) Caspase $3 / 7$ activity was expressed as $n$-fold increase relative to untreated control $(n=8$, mean \pm SEM).

involved transcriptional regulation through an androgendependent pathway, we measured the expression of Bax and $\mathrm{Bcl} 2$ and Caspase 3/7 activity in the presence of the AR antagonist flutamide. $\mathrm{Bcl} 2$ protein levels and Caspase activity decreased in the presence of $1 \mathrm{nM}$ FLU, which suggested that the antiandrogen protected prostate cells from apoptotic assaults (Figure 8). At $10 \mathrm{ppm} \mathrm{Biz-2,} \mathrm{there} \mathrm{was}$ an $80 \%$ decrease in Caspase $3 / 7$ activity in the presence of FLU (Figure 8(b)). FLU produced up to a 2-fold decrease in $\mathrm{Bcl} 2$ protein but had a notable 2-fold increase on Bax protein levels (Figure 8(a)). As with the Caspase 3/7 activity, cotreatment of Biz-2 with FLU completely blocked Biz-2induced increases in $\mathrm{Bcl} 2$ and Bax proteins. To substantiate the FLU data, we measured Bcl2-protein levels in the presence of resveratrol, which induces apoptosis in LNCaP cells [40]. Resveratrol-induced inhibition of $\mathrm{Bcl} 2$ and $\mathrm{Bax}$ expression was completely blocked by FLU (Figure 8(a)). Thus, the cytotoxic effect of Biz-2 on LNCaP cells was decreased by more than $90 \%$ in the presence of CHX or the antiandrogen FLU, and was unaffected by actinomycin-D, which suggested that the mode of action of Biz-2 involved AR pathways and protein synthesis.

\section{Discussion}

Given the high incidence of prostate cancer, there is an urgent need for treatment paradigms that improve prostate health. Nonsteroidal compounds are an interesting target for prostate cancer treatment because they do not produce the undesirable effects associated with traditional steroidal regimes $[12,39,41,42]$. The search for nonsteroidal androgen usually starts by identifying a natural compound that shows the potential of antiandrogen properties. One group of compounds that has received a tremendous amount of attention is the naturally occurring phytoestrogens found in fruits, vegetables, and teas. These compounds have also been shown to possess antiandrogenic activity due to their ability to inhibit and delay prostate cancer $[11,43]$.

Growth and normal development of the prostate gland are under the control of androgen acting through interaction with the AR. The need for new androgenic therapies to improve prostate function has centered on agents that alter the AR action. Recently, we reported that the common Jamaican herbal medicine, Bizzy, contains a putative nonsteroidal compound with bioactivity in both breast and prostate cancer cells. In this study, we applied the androgendependent LNCaP prostate tumor cell model along with the androgen-independent DU145 prostate tumor cell model to ascertain the androgenic effect of this medicinal extract. Screening of several Bizzy extracts for bioactivity using several in vitro assays was designed to evaluate whether any of the extracts contained androgenic or antiandrogenic activity [22]. The study shows that an ether extract of Bizzy (Biz-2) is the most potent inhibitor of $\mathrm{LNCaP}$ cell growth because it has a high affinity for the AR. At high concentrations, Biz-2 activates AR-dependent gene expression and induces apoptosis in LNCaP cells.

We tested the hypothesis that Bizzy nut extract can modulate prostate activity by using prostate secretion as an index of prostate function. We observed that the rate of PSA secreted by LNCaP cells in the presence of Biz-2 was sharply decreased. Biz-2 modulation of PSA production was AR-dependent, which implied that Biz-2's biological effect may serve as an index of putative phytoandrogen in prostate cancer cells. 
The key to a successfully chemopreventive agent against prostate and other types of cancer will rely on these agents' ability to induce cell death in tumor cells in a tissuedependent and even a receptor-dependent manner. The search for natural compounds capable of functioning as potential chemopreventive agents for prostate cancer has met with mixed results [19,43-45]. Natural chemopreventive agents as well as anticancer agents function by modulating one or several major steps in the carcinogenesis pathway. Naturally occurring agents that could induce apoptosis in prostate cells in an AR-dependent manner would signal a new generation of prostate-specific, chemopreventative agents. Our Biz-2 extract appears to possess some of the fundamental activities required for this type of chemopreventive agent. We demonstrated that in LNCaP cells, Biz-2 inhibits at least one family member of the natural inhibitors of apoptosis (Bcl2), which suggests that Biz-2 may force cells into the apoptotic pathway. Bcl2 and Bax are key players in apoptotic events. The ratio of these proteins determines whether a cell will commit to the apoptosis pathway. The data provided by this study point to Biz-2 as a putative chemopreventive agent in prostate cells. Biz2 showed a time-dependent and dose-dependent increase in the proapoptotic gene at both the protein and mRNA levels. The increase in proapoptotic protein was coupled to morphological signs of apoptosis and to an increase in enzyme associated with late apoptotic events. Furthermore, the ability of the antiandrogen flutamide to prevent Biz2 induction of both Caspase activity and Bcl2 expression supports the role of the AR pathway in this process. It is interesting to note that in the absence of AR, Bizz-2 may possess antiproliferative activity. In the AR-negative cell, DU145, we observed a greater degree of inhibition of cell proliferation as compared to AR-positive LNCaP cells. Correspondently, DU145 had a lower apoptotic index in the presence of Biz-2. Taken together, these observations suggest that Biz-2 may elicit antiproliferative activity that does not require a functional androgen receptor pathway.

In deciphering the role of Biz-2 in prostate function, it is important to examine the transcriptional effects of this extract on both estrogen-responsive and androgenresponsive genes. Androgen, including phytoandrogen, acts via binding of different types of ligands to the AR coalescent in gene expression. Antagonists, which inhibit the transcriptional activity of the AR, are currently being used as potential treatment agents in the fight against prostate cancer. The involvement of Biz-2 in AR biology was examined using two parameters: (1) receptor binding and (2) AR-dependent gene activation. In classical competition experiments, components of our Biz-2 extract are capable of displacing androgen from the AR. The potency of the putative androgenic compound in Biz-2 is only thirteen times lower than the potency of the synthetic androgen R1881. Examination of the transcriptional response of several androgen-regulated genes reveals a 5-fold induction in mRNA expression following a 24-hour exposure to Biz-2. Levels of expression of NKX31 or PSA, both prostate-specific genes, were elevated 5 -fold and 10-fold, respectively, by Biz-2. DHT produced a similar induction in these genes under identical conditions. We observed that Biz-2 regulated both androgen-dependent and androgen-independent genes such as Bcl2 and Bax, but was ineffective in regulating the steroid receptor mRNA levels. This study clearly demonstrated that effects of Biz-2 on transcriptional activation of AR-dependent genes suggested that Biz-2 may be androgenic at the levels of transcription.

The biological effects of natural extract containing putative phytoandrogen or phytoestrogen are multifarious. Several hypotheses aimed at explaining the diverse action of these compounds have been proposed. One prevailing hypothesis for the cancer preventative effect of phytoandrogen or phytoestrogen in prostate cancer is the activation of an apoptotic cascade by components of the natural extract. In this study, we provide evidence that Biz-2 extract has the ability to eradicate prostate cancer cells by inducing apoptosis in an apparent AR-dependent manner. Validation of these in vitro findings with an in vivo model system is warranted. Our findings highlight the need for a closer examination of Bizzy nut as a potential source of natural chemicals that may modulate prostate growth and function.

\section{Acknowledgments}

The authors would like to thank Dr. Ella Kelly for the critical editing of the manuscript. This work was supported in part by the National Institute of General Medical Sciences, MBRS/SCORE Grant no. GM076530, and in part by NIH Center for Research Resources, Grant no. P20RR16456-02R138954 given to W. Gray.

\section{References}

[1] Society, A. C., "Cancer Fact and Figures 2007," American Cancer Society, 2007.

[2] H. Adlercreutz, "Western diet and Western diseases: some hormonal and biochemical mechanisms and associations," The Scandinavian Journal of Clinical \& Laboratory Investigation, vol. 50, supplement 201, pp. 3-23, 1990.

[3] H. Adlercreutz, H. Markkanen, and S. Watanabe, "Plasma concentrations of phyto-oestrogens in Japanese men," The Lancet, vol. 342, no. 8881, pp. 1209-1210, 1993.

[4] M. Hedelin, Å. Klint, E. T. Chang, et al., "Dietary phytoestrogen, serum enterolactone and risk of prostate cancer: the cancer prostate Sweden study," Cancer Causes \& Control, vol. 17, no. 2, pp. 169-180, 2006 (Swedish).

[5] D. C. Knight and J. A. Eden, "A review of the clinical effects of phytoestrogens," Obstetrics \& Gynecology, vol. 87, no. 5, part 2, pp. 897-904, 1996.

[6] F. O. Stephens, "Phytoestrogens and prostate cancer: possible preventive role," The Medical Journal of Australia, vol. 167, no. 3, pp. 138-140, 1997.

[7] A. J. Blumenfeld, N. Fleshner, B. Casselman, and J. Trachtenberg, "Nutritional aspects of prostate cancer: a review," The Canadian Journal of Urology, vol. 7, no. 1, pp. 927-935, discussion 936, 2000.

[8] E. P. Castle and J. B. Thrasher, "The role of soy phytoestrogens in prostate cancer," Urologic Clinics of North America, vol. 29, no. 1, pp. 71-81, 2002.

[9] H. Adlercreutz, "Epidemiology of phytoestrogens," Baillière's Clinical Endocrinology and Metabolism, vol. 12, no. 4, pp. 605623, 1998. 
[10] K. Griffiths, L. Denis, A. Turkes, and M. S. Morton, "Phytoestrogens and diseases of the prostate gland," Baillière's Clinical Endocrinology and Metabolism, vol. 12, no. 4, pp. 625-647, 1998.

[11] M. Pollard, "Prevention of prostate-related cancers in Lobund-Wistar rats," The Prostate, vol. 39, no. 4, pp. 305-309, 1999.

[12] M. Pollard and W. Wolter, "Prevention of spontaneous prostate-related cancer in lobund-Wistar rats by a soy protein isolate/isoflavone diet," The Prostate, vol. 45, no. 2, pp. 101$105,2000$.

[13] S. S. Strom, Y. Yamamura, C. M. Duphorne, et al., "Phytoestrogen intake and prostate cancer: a case-control study using a new database," Nutrition and Cancer, vol. 33, no. 1, pp. 2025, 1999.

[14] J. Geller, L. Sionit, C. Partido, et al., "Genistein inhibits the growth of human-patient $\mathrm{BPH}$ and prostate cancer in histoculture," The Prostate, vol. 34, no. 2, pp. 75-79, 1998.

[15] K. S. Weber, N. A. Jacobson, K. D. Setchell, and E. D. Lephart, "Brain aromatase and $5 \alpha$-reductase, regulatory behaviors and testosterone levels in adult rats on phytoestrogen diets," Proceedings of the Society for Experimental Biology and Medicine, vol. 221, no. 2, pp. 131-135, 1999.

[16] K. S. Weber, K. D. Setchell, D. M. Stocco, and E. D. Lephart, "Dietary soy-phytoestrogens decrease testosterone levels and prostate weight without altering $\mathrm{LH}$, prostate $5 \alpha$-reductase or testicular steroidogenic acute regulatory peptide levels in adult male Sprague-Dawley rats," Journal of Endocrinology, vol. 170, no. 3, pp. 591-599, 2001.

[17] M. Hedelin, K. A. Bälter, E. T. Chang, et al., "Dietary intake of phytoestrogens, estrogen receptor-beta polymorphisms and the risk of prostate cancer," The Prostate, vol. 66, no. 14, pp. 1512-1520, 2006.

[18] P. O. Osadebe, G. B. Okide, and I. C. Akabogu, "Study on antidiabetic activities of crude methanolic extracts of Loranthus micranthus (Linn.) sourced from five different host trees," Journal of Ethnopharmacology, vol. 95, no. 2-3, pp. 133-138, 2004.

[19] M. Kamatenesi-Mugisha and H. Oryem-Origa, "Traditional herbal remedies used in the management of sexual impotence and erectile dysfunction in western Uganda," African Health Sciences, vol. 5, no. 1, pp. 40-49, 2005.

[20] D. Robertson, Jamaican Herbs: Nutritional and Medicinal Values, Vol. 1, Jamaican Herbs, Kingston, Jamaica, 1988.

[21] "Jamaican Bush Teas," 2006, http://www.Jamaican-Recipes .com.

[22] K. Fontenot, S. Naragoni, M. Claville, and W. Gray, "Characterization of Bizzy Nut extracts in estrogen-responsive MCF-7 breast cancer cells," Toxicology and Applied Pharmacology, vol. 220, no. 1, pp. 25-32, 2007.

[23] Applied Biosystems, ABI PRISM 7700 Sequence Detection System User Bulletin \#2, 2001.

[24] I. Anderson, C. R. Bartley, R. A. Lerch, W. G. N. Gray, P. D. Friesen, and J. Gorski, "Estrogen receptor $\alpha$ requires no accessory factors for high-affinity binding to a consensus response element," Biochemistry, vol. 37, no. 49, pp. 1728717298, 1998.

[25] W. G. N. Gray, E. E. Biswas, N. Bashirelahi, and S. B. Biswas, "A low-affinity estrogen-binding site in pregnant rat uteri: analysis and partial purification," Proceedings of the National Academy of Sciences of the United States of America, vol. 91, no. 24, pp. 11502-11506, 1994.

[26] W. B. Panko, C. S. Watson, and J. H. Clark, "The presence of a second, specific estrogen binding site in human breast cancer,"
Journal of Steroid Biochemistry, vol. 14, no. 12, pp. 1311-1316, 1981.

[27] Y.-C. Cheng and W. H. Prusoff, "Relationship between the inhibition constant $\left(K_{1}\right)$ and the concentration of inhibitor which causes 50 per cent inhibition $\left(I_{50}\right)$ of an enzymatic reaction," Biochemical Pharmacology, vol. 22, no. 23, pp. 30993108, 1973.

[28] S. Stahl, T.-Y. Chun, and W. G. Gray, "Phytoestrogens act as estrogen agonists in an estrogen-responsive pituitary cell line," Toxicology and Applied Pharmacology, vol. 152, no. 1, pp. 4148, 1998.

[29] W. Washington, L. Hubert, D. Jones, and W. G. Gray, "Bisphenol A binds to the low-affinity estrogen binding site," In Vitro \& Molecular Toxicology, vol. 14, no. 1, pp. 43-51, 2001.

[30] GraphPad Prism version 3.0 for Windows, GraphPad Software, San Diego, Calif, USA, http://www.graphpad.com.

[31] K. Noguchi, H. Uemura, M. Harada, et al., "Inhibition of PSA flare in prostate cancer patients by administration of flutamide for 2 weeks before initiation of treatment with slow-releasing LH-RH agonist," International Journal of Clinical Oncology, vol. 6, no. 1, pp. 29-33, 2001.

[32] T. V. Nguyen, M. Yao, and C. J. Pike, "Flutamide and cyproterone acetate exert agonist effects: induction of androgen receptor-dependent neuroprotection," Endocrinology, vol. 148, no. 6, pp. 2936-2943, 2007.

[33] L. Yu, G. L. Blackburn, and J.-R. Zhou, "Genistein and daidzein downregulate prostate androgen-regulated transcript-1 (PART-1) gene expression induced by dihydrotestosterone in human prostate LNCaP cancer cells," The Journal of Nutrition, vol. 133, no. 2, pp. 389-392, 2003.

[34] H.-G. Yoon and J. Wong, "The corepressors silencing mediator of retinoid and thyroid hormone receptor and the nuclear receptor corepressor are involved in agonist- and antagonist-regulated transcription by androgen receptor," Molecular Endocrinology, vol. 20, no. 5, pp. 1048-1060, 2006.

[35] P. S. Nelson, N. Clegg, H. Arnold, et al., "The program of androgen-responsive genes in neoplastic prostate epithelium," Proceedings of the National Academy of Sciences of the United States of America, vol. 99, no. 18, pp. 11890-11895, 2002.

[36] P. Soronen, M. Laiti, S. Törn, et al., "Sex steroid hormone metabolism and prostate cancer," The Journal of Steroid Biochemistry and Molecular Biology, vol. 92, no. 4, pp. 281286, 2004.

[37] T. L. Parker, D. L. Eggett, and M. J. Christensen, "Estrogen receptor activation and estrogen-regulated gene expression are unaffected by methylseleninic acid in LNCaP prostate cancer cells," The Journal of Nutritional Biochemistry, vol. 18, no. 11, pp. 746-752, 2007.

[38] J. Veldscholte, C. A. Berrevoets, C. Ris-Stalpers, et al., "The androgen receptor in $\mathrm{LNCaP}$ cells contains a mutation in the ligand binding domain which affects steroid binding characteristics and response to antiandrogens," The Journal of Steroid Biochemistry and Molecular Biology, vol. 41, no. 3-8, pp. 665-669, 1992.

[39] D. Yin, W. Gao, J. D. Kearbey, et al., "Pharmacodynamics of selective androgen receptor modulators," Journal of Pharmacology and Experimental Therapeutics, vol. 304, no. 3, pp. 1334-1340, 2003.

[40] C. Gill, S. E. Walsh, C. Morrissey, J. M. Fitzpatrick, and R. W. G. Watson, "Resveratrol sensitizes androgen independent prostate cancer cells to death-receptor mediated apoptosis through multiple mechanisms," The Prostate, vol. 67, no. 15, pp. 1641-1653, 2007. 
[41] H. T. Le, C. M. Schaldach, G. L. Firestone, and L. F. Bjeldanes, "Plant-derived 3,3'-diindolylmethane is a strong androgen antagonist in human prostate cancer cells," Journal of Biological Chemistry, vol. 278, no. 23, pp. 21136-21145, 2003.

[42] M. Bonham, H. Arnold, B. Montgomery, and P. S. Nelson, "Molecular effects of the herbal compound PC-SPES: identification of activity pathways in prostate carcinoma," Cancer Research, vol. 62, no. 14, pp. 3920-3924, 2002.

[43] N. B. Kumar and K. Besterman-Dahan, "Nutrients in the chemoprevention of prostate cancer: current and future prospects," Cancer Control, vol. 6, no. 6, pp. 580-586, 1999.

[44] F. H. Sarkar and Y. Li, "Mechanisms of cancer chemoprevention by soy isoflavone genistein," Cancer and Metastasis Reviews, vol. 21, no. 3-4, pp. 265-280, 2002.

[45] J. M. Holzbeierlein, J. McIntosh, and J. B. Thrasher, "The role of soy phytoestrogens in prostate cancer," Current Opinion in Urology, vol. 15, no. 1, pp. 17-22, 2005. 

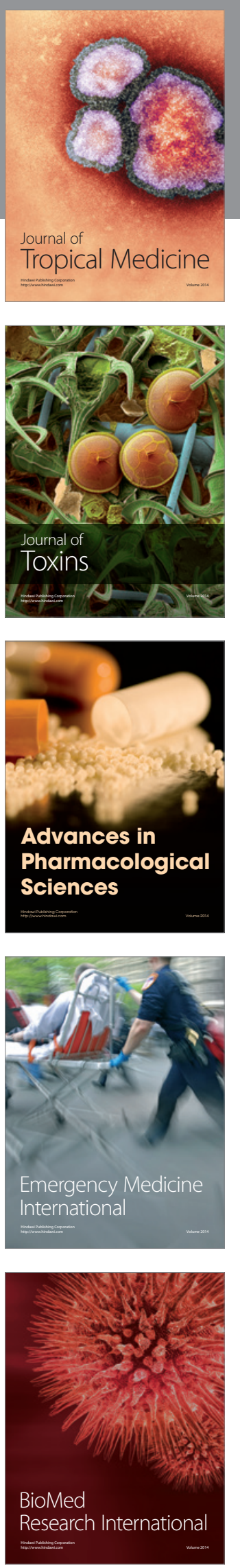
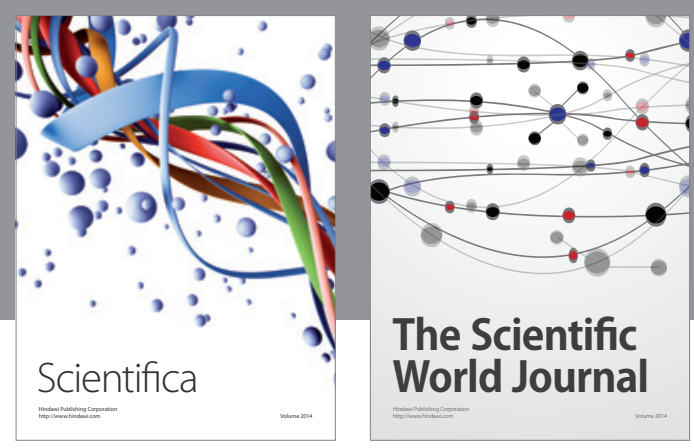

The Scientific World Journal
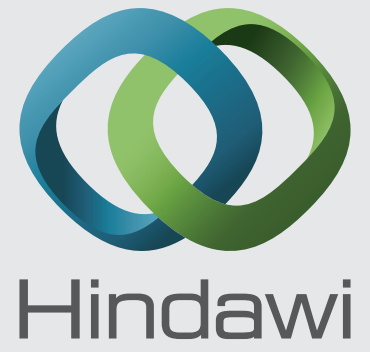

Submit your manuscripts at

http://www.hindawi.com
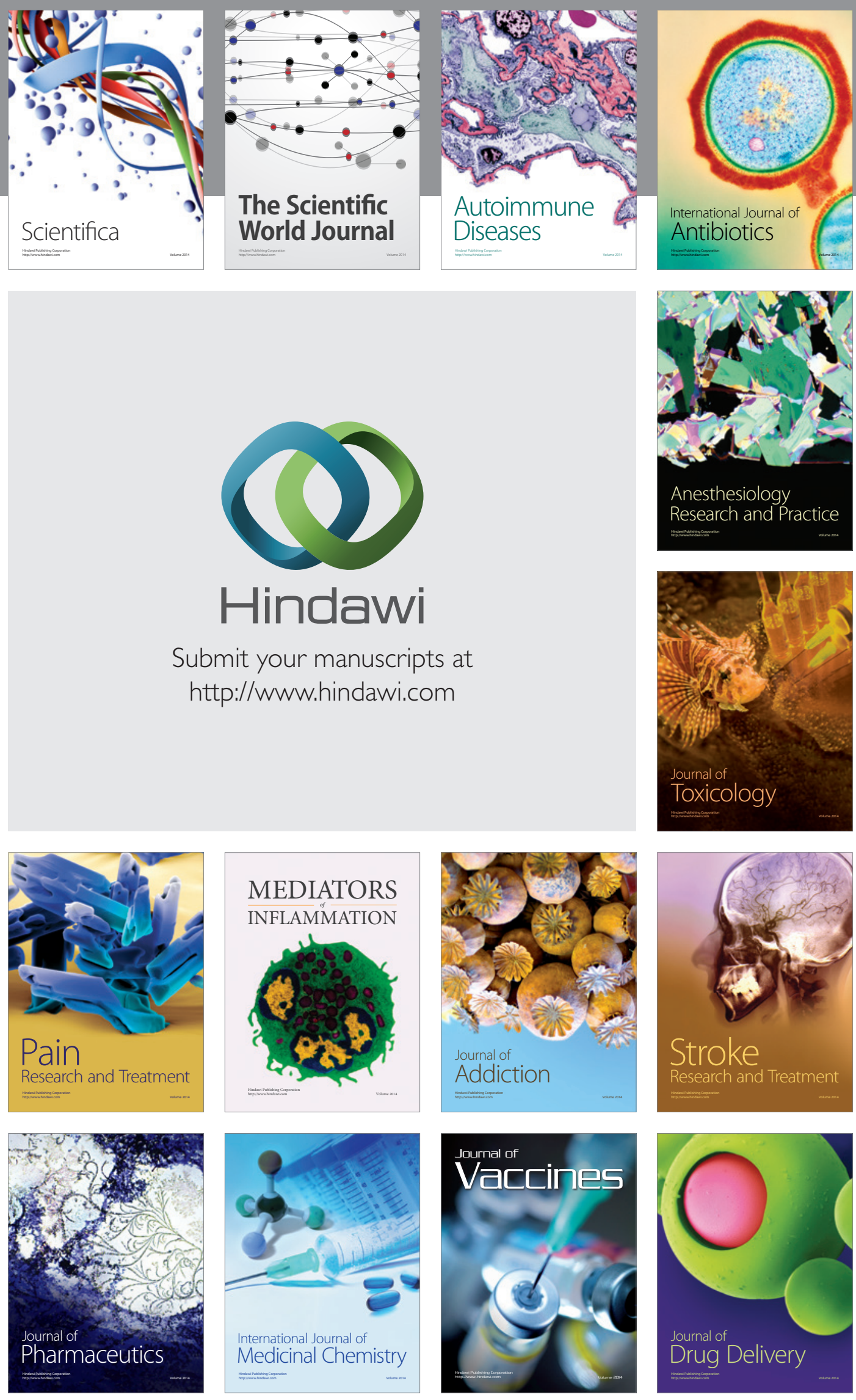